\title{
Seismic imaging in the eastern Scandinavian Caledonides: siting the 2.5 km deep COSC-2 borehole, central Sweden
}

\author{
Christopher Juhlin, Peter Hedin, David G. Gee, Henning Lorenz, Thomas Kalscheuer, and Ping Yan \\ Department of Earth Sciences, Uppsala University, Uppsala, Sweden \\ Correspondence to: Peter Hedin (peter.hedin@geo.uu.se)
}

Received: 1 December 2015 - Published in Solid Earth Discuss.: 15 January 2016

Revised: 13 April 2016 - Accepted: 28 April 2016 - Published: 18 May 2016

\begin{abstract}
The Collisional Orogeny in the Scandinavian Caledonides (COSC) project, a contribution to the International Continental Scientific Drilling Program (ICDP), aims to provide a deeper understanding of mountain belt dynamics. Scientific investigations include a range of topics, from subduction-related tectonics to the present-day hydrological cycle. COSC investigations and drilling activities are focused in central Scandinavia, where rocks from the middle to lower crust of the orogen are exposed near the SwedishNorwegian border. Here, rock units of particular interest occur in the Seve Nappe Complex (SNC) of the so-called Middle Allochthon and include granulite facies migmatites (locally with evidence of ultra-high pressures) and amphibolite facies gneisses and mafic rocks. This complex overlies greenschist facies metasedimentary rocks of the doleriteintruded Särv Nappes and underlying, lower grade Jämtlandian Nappes (Lower Allochthon). Reflection seismic profiles have been an important component in the activities to image the subsurface structure in the area. Subhorizontal reflections in the upper $1-2 \mathrm{~km}$ are underlain and interlayered with strong west- to northwest-dipping reflections, suggesting significant east-vergent thrusting. Two $2.5 \mathrm{~km}$ deep fully cored boreholes are a major component of the project, which will improve our understanding of the subsurface structure and tectonic history of the area. Borehole COSC-1 (IGSN: http://hdl.handle.net/10273/ICDP5054EEW1001), drilled in the summer of 2014, targeted the subduction-related Seve Nappe Complex and the contact with the underlying allochthon. The COSC-2 borehole will be located further east and will investigate the lower grade, mainly Cambro-Silurian rocks of the Lower Allochthon, the Jämtlandian décollement, and penetrate into the crystalline basement rocks to identify the source of some of the northwest-dipping reflections.
\end{abstract}

A series of high-resolution seismic profiles have been acquired along a composite ca. $55 \mathrm{~km}$ long profile to help locate the COSC drill holes. We present here the results from this COSC-related composite seismic profile (CSP), including new interpretations based on previously unpublished data acquired between 2011 and 2014. These seismic data, along with shallow drill holes in the Caledonian thrust front and previously acquired seismic, magnetotelluric, and magnetic data, are used to identify two potential drill sites for the COSC-2 borehole.

\section{Introduction}

Following the Ordovician closure of the Iapetus Ocean, major Caledonian orogeny involved continent collision and underthrusting of Baltica beneath Laurentia. Subductionrelated metamorphism along the Baltica margin already took place in the early to middle Ordovician (Gee et al., 2012; Majka et al., 2012) and the initial stages of continent-continent collision are believed to have occurred around $445 \mathrm{Ma}$ (e.g., Ladenberger et al., 2012, 2014). Thrust tectonics, which dominated throughout the collision, resulted in the emplacement of allochthonous units both westwards onto the Laurentian platform of Greenland (Higgins and Leslie, 2000), with displacements of the higher allochthons at least $200 \mathrm{~km}$, and eastwards onto the Baltoscandian platform, with displacements of more than $500 \mathrm{~km}$ (Gee, 1978).

Towards the end of Caledonian orogeny, in the early Devonian, the mountain belt was in many aspects comparable to the presently active Himalaya-Tibet orogen (Dewey, 1969; Gee et al., 2010; Labrousse et al., 2010). Following postorogenic collapse, extension, and deep erosion, the surface of 
the present-day Caledonides cuts through the internal architecture of the paleo-orogen, revealing the nappe structure at mid-crustal depths. The Scandinavian mountains, the Scandes, have long been recognized as an excellent environment to study thrust tectonics (Törnebohm, 1888) and the processes involved in continent-continent collision (Gee, 1975; Hossack and Cooper, 1986).

Investigations of the Scandinavian Caledonides (Fig. 1) were intensified in the 1970s (Gee and Sturt, 1985) and our understanding has improved since then through continued geological (e.g., the many contributions in Corfu et al., 2014) and numerous geophysical (e.g., Dyrelius, 1980, 1986; Elming, 1988; Hurich et al., 1989; Palm et al., 1991; Hurich, 1996; Juhojuntti et al., 2001; Pascal et al., 2007; Korja et al., 2008; England and Ebbing, 2012) studies. One key area of investigation (Dyrelius et al., 1980) has been along a profile crossing the mountain belt through the provinces of Jämtland (Sweden) and Tröndelag (Norway). Reflection seismic surveys were conducted along the Central Caledonian Transect (CCT), which stretches from the east of the Caledonian thrust front in central Jämtland to the Atlantic coast in western Tröndelag (Hurich et al., 1989; Palm et al., 1991; Hurich, 1996; Juhojuntti et al., 2001). The highly reflective upper crust shows a reflectivity pattern of crustal shortening consistent with surface observations, i.e., imbrication of allochthonous units and folding by major N-S to NE-SWtrending antiforms and synforms.

At the thrust front in central Sweden, Cambrian alum shales, deposited unconformably on the autochthonous crystalline basement, are separated from the overlying Caledonian allochthons by a major décollement (Gee et al., 1978). Comprehensive drilling programs targeting the metalliferous organic-rich alum shales (Gee et al., 1982) in the thrust front south of lake Storsjön reached about $30 \mathrm{~km}$ to the northwest, establishing a $1-2^{\circ}$ westwards dip of the décollement. At the Caledonian front in central Jämtland, this major detachment coincides with the Caledonian sole thrust (see profile in Fig. 1). We define the main décollement (in Jämtland the Jämtlandian décollement, at the base of the Jämtlandian Nappes) as the thrust zone that separates all the overlying long-transported allochthons from the underlying less deformed basement. The sole thrust corresponds to the lower limit of Caledonian deformation, i.e., involving both the long-transported allochthons and the underlying crystalline basement in and below the antiformal windows. Along the CCT reflection seismic profile, the sole thrust in the western part (Palm et al., 1991) was inferred to ramp up eastwards and pass into the Jämtlandian décollement, as defined in areas north of Storsjön (Juhojuntti et al., 2001). The sole thrust defined by Palm et al. (1991) beneath the Åre Synform and Mullfjället Antiform was inferred to continue westwards to the Swedish-Norwegian border, where it appears to reach a depth of ca. $7 \mathrm{~km}$ (Hurich et al., 1989), perhaps deeper (Gee, 1988, Hurich, 1996), beneath the imbricated crystalline basement of the Skardöra Antiform. This interpre-
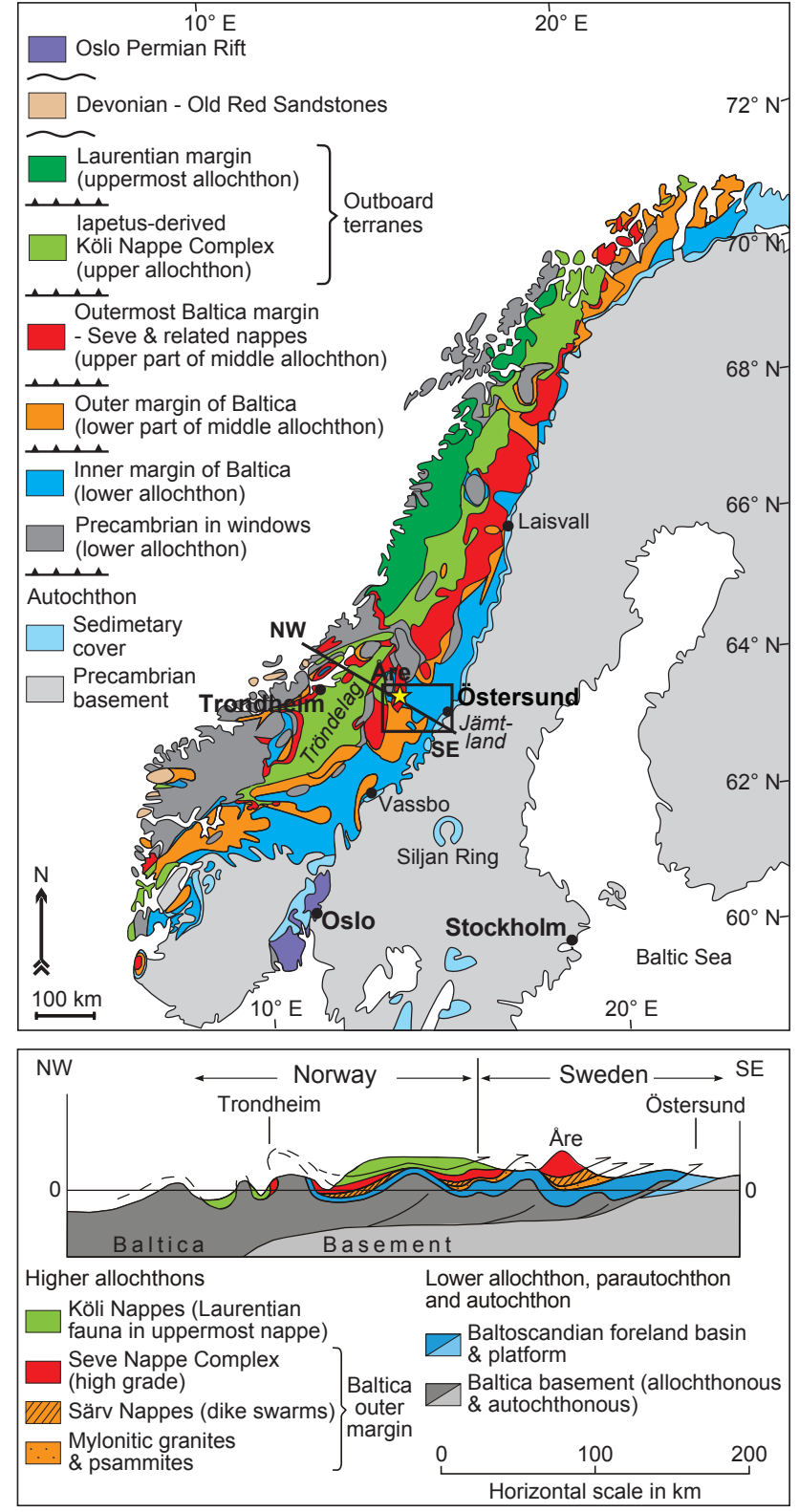

Figure 1. (a) Provenance interpretation of the tectonostratigraphic map of the Scandinavian Caledonides, modified from Gee et al. (1985). The star marks the location of the COSC-1 borehole. (b) Schematic cross section (vertical exaggeration $\mathrm{x} 10$ ) along the NW-SE profile in (a), from Gee et al. (2010). The autochthonous basement (light gray) is separated from the Caledonian deformed basement (dark gray) by the Scandian sole thrust.

tation is in agreement with previous modeling of refraction seismic (Palm, 1984), aeromagnetic (Dyrelius, 1980), and gravity data (Dyrelius, 1985; Elming, 1988). Magnetotelluric measurements along the Swedish section of the CCT profile (Korja et al., 2008), targeting the highly conductive alum shales, further support this interpretation. 
A transition from thin-skinned (where deformation is mostly restricted to the allochthonous sediment-dominated units) to thick-skinned tectonics (with deep crustal deformation and basement shortening) is often attributed to large-scale detachments and fault systems in the hinterland (Hurich, 1996; Mosar, 2003; Fossen et al., 2014) that are reactivated during post-collisional extension. In the case of the Caledonides, these are late-orogenic and involve NE-SW extension along the axis of the orogen. However, the previous thrusting may well have been influenced by the preCaledonian geometry of the rifted and extended Neoproterozoic margin of Baltica (Gee et al., 2012).

Juhojuntti et al. (2001) identified a present-day Moho at a depth of ca. $45-50 \mathrm{~km}$ beneath central Sweden and suggested deep crustal deformation in the subducting Baltica plate. However, the source of the strong reflections observed from within the Paleoproterozoic basement beneath Jämtland remains to be determined. Two potential sources of the reflectivity patterns have been proposed (Palm et al., 1991, Juhojuntti et al., 2001), one being that they are related to the deformation history and the other that they are lithological in origin. Deformation zones could have developed during the Caledonian or Precambrian (Sveconorwegian, ca. 1.0 Ga, or older) orogenies. Alternatively, most of the reflections could represent deformed mafic intrusions in the dominantly granitic basement rocks. Dolerite sills in the Siljan Ring area, $100 \mathrm{~km}$ to the southeast, are known to generate a similar seismic response (Juhlin, 1990). Dolerite sills and dykes are found to the south $(0.95 \mathrm{Ga}$, Juhlin, 1990; Högdahl et al., 2004 ) and east (1.25 Ga, Högdahl et al., 2004; Söderlund et al., 2006) of the thrust front of the central Scandinavian Caledonides and also in the Olden Window (Sjöström and Talbot, 1987).

The Collisional Orogeny in the Scandinavian Caledonides (COSC) project (Gee et al., 2010; Lorenz et al., 2011) aims to improve our understanding of collisional orogeny through scientific deep drilling of selected targets in the Swedish Caledonides. COSC is supported by the International Continental Scientific Drilling Program (ICDP) and operates within the framework of the Swedish Scientific Drilling Program (SSDP), which has the objective to investigate fundamental questions of global importance that are well defined in Scandinavia and require drilling.

The first phase of the project, COSC-1, targeted the lower units of the high-grade Seve Nappe Complex (SNC). These rocks that originated along the rifted outer margin of continent Baltica, including the continent-ocean transition (COT) zone (Andreasson, 1994), were partially subducted during the Ordovician and then emplaced hot onto underlying allochthons. COSC-1 was drilled to a depth of $2.5 \mathrm{~km}$ with almost $100 \%$ core recovery during May to August 2014 (Lorenz et al., 2015). The second phase, COSC-2, involves a second $2.5 \mathrm{~km}$ deep borehole that will start in the Lower Allochthon and aims to penetrate the Jämtlandian décollement as well as at least one of the underlying enigmatic basement reflectors. The focus of COSC-2 lies in understanding the thin-skinned thrusting over this detachment horizon, the character of the deformation in the underlying crystalline Fennoscandian basement, and how this foreland deformation relates to the partial subduction of the Baltica margin in the hinterland (e.g., the Western Gneiss Region of southwestern Norway) in the early Devonian (Robinson et al., 2014).

In 2010, a $36 \mathrm{~km}$ long high-resolution reflection seismic profile was acquired in the Åre area (Fig. 1) with the purpose of finding the most suitable locations for the two scientific boreholes (Hedin et al., 2012). The location of the COSC1 borehole was defined from these data (together with logistical considerations), but a location fulfilling the requirements of COSC-2 was not clearly identified. The interpreted Jämtlandian décollement and basement reflections appeared to continue shallowing towards the east, and the main seismic profile was therefore extended by about $17 \mathrm{~km}$ in 2011 and another ca. $14 \mathrm{~km}$ in 2014. A substantial gap in the 2011 acquisition was bridged in 2014 by an additional ca. $16 \mathrm{~km}$ long highly crooked profile south of the 2011 profile (Fig. 2).

Complementary to the seismic profiling, a magnetotelluric (MT) survey was conducted along the entire seismic profile in 2013 (Yan et al., 2016). Although this also suffered from the need for a diversion and, thus, follows the highly crooked seismic profile, it provides clear constraints on the depth to the top of the highly conductive alum shales. In addition, new aeromagnetic data were acquired by the Swedish Geological Survey in 2011, showing prominent features that may be linked with Rätan-type magnetite-rich granites in the basement.

This paper focuses on the interpretation of the recently acquired seismic profiles, together referred to as the COSC seismic profile (CSP), and the linking of these with the results from the drilling program in the late 1970s and observations from the COSC-1 borehole. In the light of the new geophysical data (reflection seismic, MT, and aeromagnetic), we present an updated and extended interpretation of the seismic section from Hedin et al. (2012), along with alternative interpretations of the Jämtlandian décollement and the sole thrust. Based on our interpretations of the CSP data and the goals of the COSC scientific deep drilling project, we propose two candidate locations for the second borehole, COSC-2.

\section{Caledonian geology and the central Jämtland profile}

As mentioned above, the Caledonian allochthons in the thrust front of the orogen are separated from the underlying Precambrian crystalline basement by the major Jämtlandian décollement. Along most of the orogenic front in Scandinavia and in the basement windows further west, this décollement is associated with Cambrian black alum shales (Andersson et al., 1985) which were deposited unconformably on the basement, prior to thrust emplacement of the overlying nappes. These kerogen-rich shales, with carbon contents up to $15 \%$, acted as a lubricant to facilitate the low angle thrusting of 


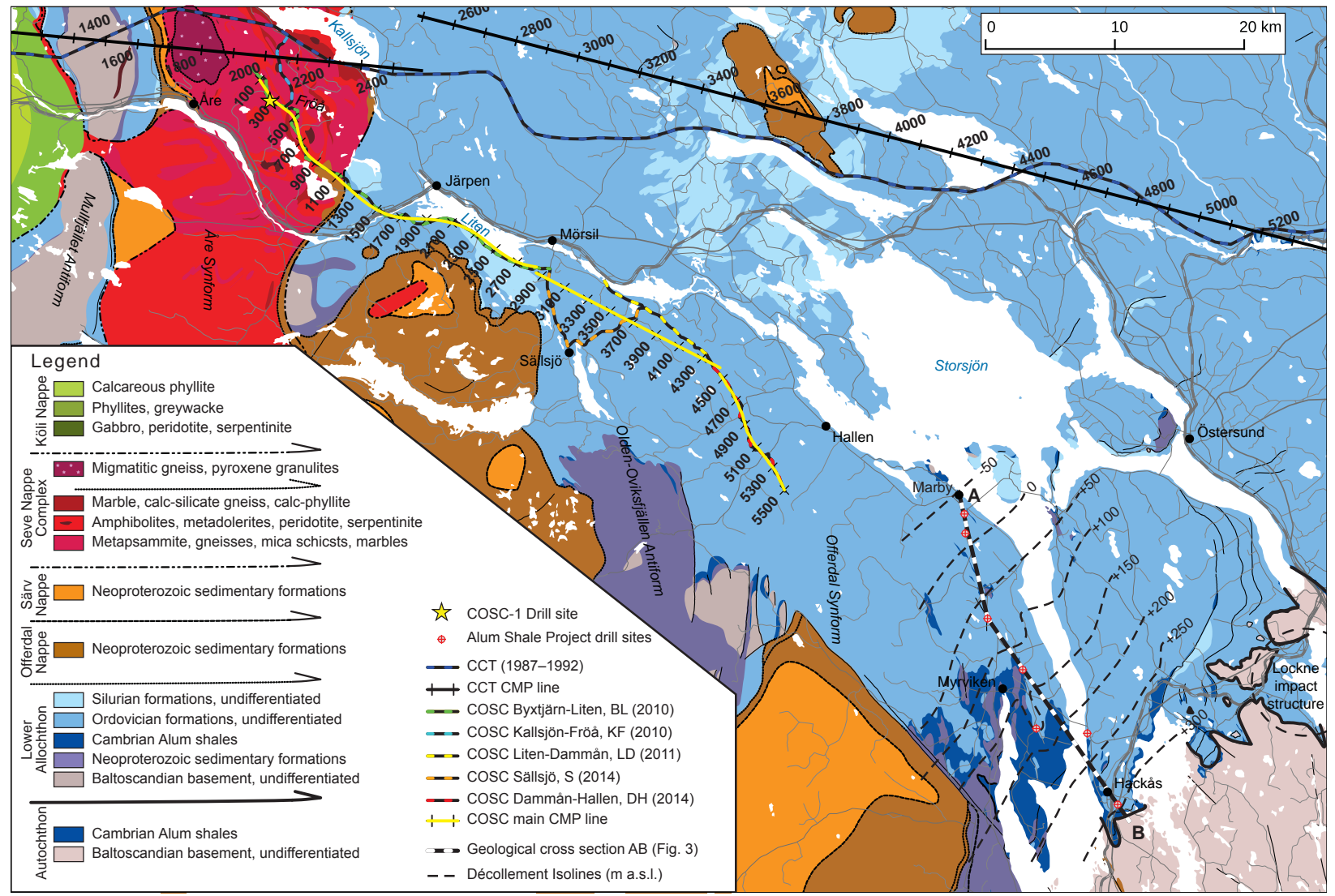

Figure 2. Bedrock geological map of western Jämtland, based on the bedrock geological map of Sweden, ${ }^{\odot}$ Geological Survey of Sweden [I2014/00601] and Strömberg et al. (1984), showing the locations of the CSP and CCT seismic profiles, the COSC-1 borehole, and the shallow drill holes in the Myrviken area. The location of the geological cross section, shown in Fig. 3, is also indicated.

the nappes for hundreds of kilometers onto the continental margin and platform of Baltica.

The Scandian nappes are commonly grouped into four major assemblages - Lower, Middle, Upper, and Uppermost, as originally proposed for the Swedish Caledonides by Kulling (in Strand and Kulling, 1972), depending upon their level in the thrust system (Gee et al., 1985). Baltoscandian platform, inner margin, and foreland basin strata dominate the Lower Allochthon. The outer margin and COT assemblages are generally thought to comprise the Middle Allochthon. Iapetus ocean-derived terranes characterize the Upper Allochthon and, at the top (Uppermost Allochthon), fragments of continental margin affinities are inferred to have been derived from Laurentia (Fig. 1). All these allochthons, together, are influenced by late orogenic shortening, with the development of major antiforms and synforms on N-S to NE-SWtrending axes. Many of the antiforms expose basement-cover relationships. In western Jämtland, the lithologies that comprise the Lower, Middle, and Upper allochthons are well developed and distinct. The tectonostratigraphic level of the exposed rocks increases from east to west.
The Caledonian geology was mapped and compiled at a $1: 200000$ scale by Strömberg et al. (1984), and described by Karis and Strömberg (1998). Their work provides the basis for the map presented in Fig. 2. The bedrock geology of central and western Jämtland was summarized in the context of the COSC project by Gee et al. (2010). Therefore, we focus the geological overview in this paper on an ESE-WNWdirected profile that starts in the crystalline basement just east of Hackås (Fig. 2) and passes through the Jämtlandian Nappes, via Myrviken, where extensive drilling in the 1970s investigated the alum shales and the Jämtlandian décollement, as far west as Marby. A few kilometers farther west, near Hallen, the new seismic profile (CSP) starts and continues westwards through the Jämtlandian Nappes to merge into the 2010 profile that crosses the Lower Seve Nappe and ends at Byxtjärn, just east of Åre (Fig. 2). The westernmost part of this profile, the Byxtjärn-Liten (BL) reflection seismic profile, was reported on in detail by Hedin et al. (2012).

Mapping of the many river sections transecting the Caledonian thrust front in the Scandes provided early investigators of the mountain belt with clear evidence of a very gently W-dipping Precambrian basement surface (unconformity), 


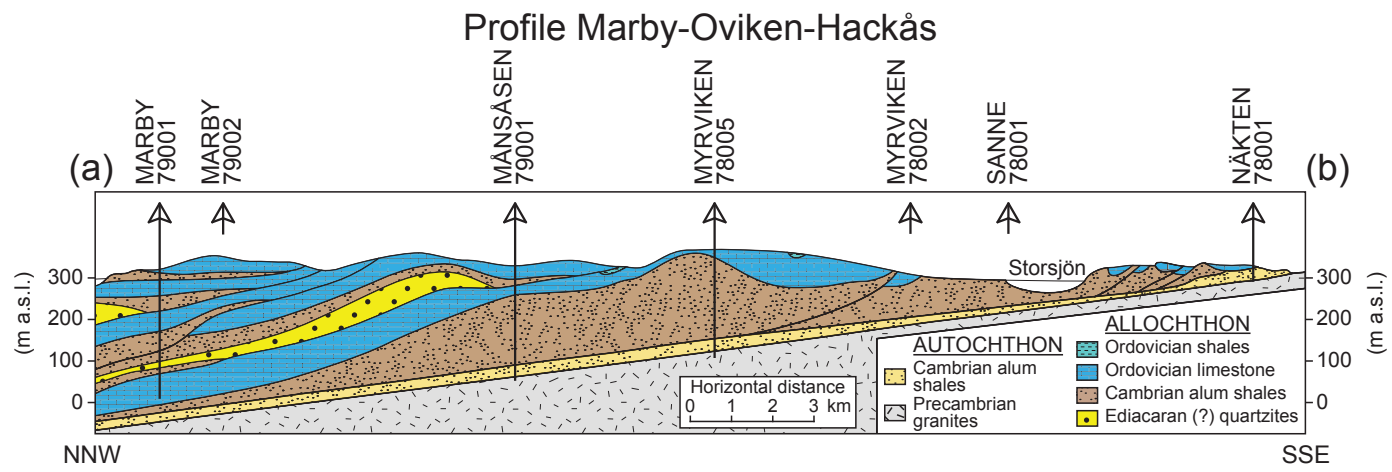

Figure 3. Geological cross section through the Myrviken area boreholes based on the SGU report on alum shales (Gee et al., 1982), shown at a vertical exaggeration of $10: 1$.

overlain by thin autochthonous Cambrian sandstones and shales (locally also Neoproterozoic sandstones and tillites, and Ordovician limestones), beneath the Jämtlandian décollement. Prospecting for lead and zinc sulfide mineralizations in the sandstones (e.g., Grip, 1960; Saintilan et al., 2015), for example in the Laisvall and Vassbo areas (Fig. 1), provided supporting evidence for these observations. Subsequent, wide-ranging drilling programs by the Geological Survey of Sweden, targeting trace element concentrations in the metalliferous Cambrian Alum Shale Formation (Gee et al., 1982) and, more locally, in directly overlying limestones (Gee et al., 1978), defined the thrust front geometry to extend regularly westwards in the order of $30-40 \mathrm{~km}$ towards the hinterland, dipping at an angle of $1-2^{\circ}$ to the westnorthwest.

\subsection{From the Caledonian front to Marby}

In the Myrviken area in central Jämtland (Fig. 2), south of Storsjön, the drilling program (Gee et al., 1982) defined the geometry of an exceptionally thick (up to $180 \mathrm{~m}$ ) alum shale unit directly overlying the Caledonian sole thrust (here corresponding to the Jämtlandian décollement). Twenty-eight drill holes (all cored) provided the basis for identifying a major low-grade uranium, vanadium, molybdenum, and nickel resource in the organic-rich alum shales. Most of the holes also penetrated a thin sandstone-dominated autochthonous Cambrian sedimentary succession overlying late Paleoproterozoic granites of the crystalline basement. Within the allochthonous units, both quartzites, stratigraphically underlying the alum shales, and limestones overlying them, occur in an imbricate stack that comprises the so-called Jämtlandian Nappes of the Lower Allochthon.

The above-mentioned drill holes allow the décollement surface to be mapped in the Myrviken area (Fig. 2) and it shows the typical character of the Caledonian thrust front throughout most of the mountain belt. Interestingly, the fold axes in the allochthon in this area trend approximately $\mathrm{N}-\mathrm{S}$ instead of NE-SW, possibly due to an anomalous basement high, ca. $50 \mathrm{~km}$ to the northeast in the Lockne area (Fig. 2), the result of a middle Ordovician meteorite impact (Lindström et al., 1996). Cross-sections through the area of southern Storsjön illustrate the structure of the imbricate stack (Andersson et al., 1985). Figure 3 shows a $25 \mathrm{~km}$ long profile trending NW, and partly NNW, from the thrust front near Hackås to Marby (Gee et al., 1982), oriented approximately parallel to the dip of the Jämtlandian décollement. This drillhole-based profile ends about $10 \mathrm{~km}$ east of the eastern termination of the Dammån-Hallen $(\mathrm{DH})$ seismic profile. If account is taken of the klippe (tectonic outlier) occurring to the south-southeast of Hackås in the Bingsta area, the Jämtlandian décollement can be inferred to provide a regular surface, dipping about $1^{\circ}$ west-northwest, over a distance of ca. $40 \mathrm{~km}$.

\subsection{From Hallen to Liten}

The exposed and near-surface bedrock between the village of Hallen and Lake Liten is dominated by Ordovician turbidites of the Jämtlandian Nappes. Only in the area of southeastern Liten are younger strata (lower Silurian, including quartzites, limestones, black shales, and, perhaps, turbidites) preserved locally in a shallow NW-trending syncline. Together with thick underlying Ordovician turbidites, this Jämtlandian sedimentary succession is folded, regionally, on approximately $\mathrm{N}$-trending axes and apparently imbricated by thrusting that is best exposed to the south of the CSP in the N-plunging Oviksfjällen Antiform. The latter is inferred to be a southern continuation of the Olden Antiform and, as shown on the Strömberg et al. (1984) map, comprises thrust sheets dominated by early Cambrian (perhaps late Ediacaran) quartzites, minor alum shales, and subordinate slices of basement-derived felsic volcanic rocks, similar to the porphyritic rhyolites outcropping in the Mullfjället Antiform, to the west of the Åre Synform. 


\subsection{From Liten to Byxtjärn}

Between Liten and Byxtjärn, near Undersåker, the seismic profile crosses the thrust between the Lower and Middle allochthons. The former is composed of low to sub-greenschist facies Ordovician turbidites, locally passing up into early Silurian strata. In the hanging wall, the Seve Nappe Complex of the Middle Allochthon dips gently westwards in the eastern limb of the Åre Synform. It comprises mainly quartzites and subordinate calcsilicate-rich psammitic gneisses and marbles, with abundant amphibolitized dolerites and gabbros and some, usually isolated, ultramafites. These rocks comprise a highly reflective assemblage as found in the seismic investigations over the Åre and Tännfors synforms (Palm et al., 1991) and in the more recent seismic data presented in Hedin et al. (2012). Along the thrust contact between the Seve Nappe Complex and the underlying strongly folded and intensely foliated turbidites of the Lower Allochthon, there occurs a sheet of felsic gneisses, locally underlain by a few tens of meters of ductilely deformed Särv Nappe metasandstones and concordant greenstones. Based on the seismic data acquired over the Åre Synform to date (Palm et al., 1991; Hedin et al., 2012, 2016), prominent reflective units that do not crop out in the eastern limb of the synform are expected to be present at depth further west, beneath its central and western parts. Results from the $2.5 \mathrm{~km}$ deep COSC-1 borehole show that the reflectivity of the Seve Nappe Complex is due to the contrast between the high metamorphicgrade gneisses and amphibolites (Hedin et al., 2016). Some of the reflections originating from below the bottom of the borehole, interpreted not to be part of the Seve Nappe Complex, can be traced towards the east, but do not extend to the surface.

In the western limb of the Åre Synform and the axial zone of the Mullfjället Antiform, Tiren (1981) mapped a detachment close above the basement and described relationships similar to those in the Caledonian front, i.e., with most of the quartzites, alum shales, and overlying turbidites being allochthonous in relation to the underlying Precambrian acid volcanic rocks with their thin unconformable veneer of alum shales and limestones.

\section{Acquisition of the COSC seismic profile (CSP)}

Seismic acquisition parameters for the reflection seismic profiles from 2011 and 2014 were similar to those of the Byxtjärn-Liten (BL) and Kallsjön-Fröå (KF) segments, presented by Hedin et al. (2012) and summarized in Table 1. Crooked line acquisition was necessary along all the profiles due to the need to follow existing roads and paths. In general, an asymmetric split spread geometry was employed that continuously moved with respect to the source. The acquisition varied slightly from profile to profile (depending on e.g., the terrain, road permissions). In addition, for the data acquired in 2014, changes were made to the source and record- ing equipment. The CSP segments that are presented in this paper are summarized below.

\subsection{Byxtjärn-Liten (BL, 2010)}

More than 1800 source points were activated along a $36 \mathrm{~km}$ long profile (Fig. 2) using a rock-breaking hydraulic hammer (VIBSIST) mounted on a front end loader. Nominal source and receiver spacing was $20 \mathrm{~m}$ and a split spread of 360 active channels using $28 \mathrm{~Hz}$ geophones was rolled along with the source. In two locations of greater interest, the source point spacing was decreased to $10 \mathrm{~m}$ to increase the local fold. No source points were activated at the first 124 receiver locations (in the terrain), or along a few short parts in the western half (no permission to activate the source), resulting in a decreased fold in these areas. The fold along the entire profile therefore shows significant variation (Hedin et al., 2012).

\subsection{Liten-Dammån (LD, 2011)}

Acquisition of the Liten-Dammån profile used the same VIBSIST source as for the Byxtjärn-Liten profile. Permission to activate the source and plant receivers was not obtained along a nearly $4.5 \mathrm{~km}$ stretch of road close to the beginning of this profile, leaving a gap in the acquisition geometry between the Byxtjärn-Liten and Liten-Dammån profiles (Fig. 2). This was partially bridged by using wireless receivers on the western side of the gap, coinciding with the last $1 \mathrm{~km}$ of the ByxtjärnLiten profile, while wired receivers were placed on the eastern side. Source points were activated on both sides of the gap to undershoot it as much as possible. However, complete undershooting was not obtained.

\subsection{Dammån-Hallen (DH, 2014)}

The main profile of 2014 was the $14 \mathrm{~km}$ eastwards extension of the Byxtjärn-Liten and Liten-Dammån profiles, beginning at Dammån and ending south of Hallen (Fig. 2). Acquisition parameters for this profile differed from the ByxtjärnLiten and Liten-Dammån profiles in that a different source was used, and $28 \mathrm{~Hz}$ geophones were used instead of $10 \mathrm{~Hz}$ geophones. More importantly, the source was less powerful. A $400 \mathrm{~kg}$ weight drop mounted on a small Bobcat excavator replaced the VIBSIST source. Previous studies (Sopher et al., 2014; Place et al., 2015) showed that this source could provide enough energy to image the subsurface to the depths of interest for the project, assuming thin Quaternary cover and shallow depths to bedrock.

\subsection{Sällsjö (S, 2014)}

To resolve the structures not imaged properly in the $4.5 \mathrm{~km}$ gap of the Liten-Dammån profile, especially in the uppermost $2 \mathrm{~km}$, a $16 \mathrm{~km}$ long profile was designed to fully bridge this gap. Starting at the same location as the Liten-Dammån profile and overlapping with the last $1 \mathrm{~km}$ of the Byxtjärn- 
Table 1. Acquisition parameters for the Byxtjärn-Liten profile (BL, 2010), Liten-Dammån profile (LD, 2011), Sällsjö profile (S, 2014) and Dammån-Hallen profile (DH, 2014).

\begin{tabular}{|c|c|c|c|c|}
\hline Profile & BL (2010) & LD (2011) & S (2014) & DH (2014) \\
\hline Spread type & Split spread & Split spread & Split spread & Split spread \\
\hline Number of channels & $300-360$ & $330-396$ & $280-360$ & $300-360$ \\
\hline Near offset & $0 \mathrm{~m}$ & $0 \mathrm{~m}$ & $0 \mathrm{~m}$ & $0 \mathrm{~m}$ \\
\hline Maximum offset & $6804 \mathrm{~m}$ & $9502 \mathrm{~m}$ & $4633 \mathrm{~m}$ & $4634 \mathrm{~m}$ \\
\hline Receiver spacing & $20 \mathrm{~m}$ & $20 \mathrm{~m}$ & $20 \mathrm{~m}$ & $20 \mathrm{~m}$ \\
\hline Receiver type & $28 \mathrm{~Hz}, 1 \mathrm{C}$ & $28 \mathrm{~Hz}, 1 \mathrm{C}$ and $3 \mathrm{C}$ & $10 \mathrm{~Hz}, 1 \mathrm{C}$ & $10 \mathrm{~Hz}, 1 \mathrm{C}$ \\
\hline Source spacing & $20 \mathrm{~m}(10 \mathrm{~m})$ & $20 \mathrm{~m}$ & $20 \mathrm{~m}$ & $20 \mathrm{~m}$ \\
\hline Source type & VIBSIST & VIBSIST & Weight drop & Weight drop \\
\hline Hit interval for hammer & $100-400 \mathrm{~ms}$ & $100-400 \mathrm{~ms}$ & - & - \\
\hline Sweeps per source point & $3-4$ & $4-5$ & - & - \\
\hline Weight drops per source point & - & - & 8 & 8 \\
\hline Nominal fold & $150-180$ & $165-200$ & $140-180$ & $150-180$ \\
\hline Recording instrument & SERCEL 408 XL & SERCEL $428 \mathrm{XL}$ & SERCEL $428 \mathrm{XL}$ & SERCEL $428 \mathrm{XL}$ \\
\hline Field low cut & - & - & - & - \\
\hline Field high cut & - & - & - & - \\
\hline Sample rate & $1 \mathrm{~ms}$ & $1 \mathrm{~ms}$ & $1 \mathrm{~ms}$ & $1 \mathrm{~ms}$ \\
\hline Record length & $26 \mathrm{~s}$ & $29 \mathrm{~s}$ & $28 \mathrm{~s}$ & $28 \mathrm{~s}$ \\
\hline Profile length & $\sim 36 \mathrm{~km}$ & $\sim 17 \mathrm{~km}$ & $\sim 16 \mathrm{~km}$ & $\sim 14 \mathrm{~km}$ \\
\hline Source points & 1807 & 638 & 767 & 626 \\
\hline Data acquired & $30 / 7-13 / 8 / 2010$ & $10-19 / 10 / 2011$ & $18-24 / 10 / 2014$ & $26-30 / 10 / 2014$ \\
\hline
\end{tabular}

Liten profile, the Sällsjö profile took a more southern route via the village of Sällsjö before turning north and merging with the Liten-Dammån profile (Fig. 2). Identical acquisition parameters to the Dammån-Hallen profile were used, that is, the same source, recording system, and spread.

\section{Processing}

Since drilling is targeted to $2.5 \mathrm{~km}$ and previous studies have shown source penetration depth generally to be to $5-6 \mathrm{~km}$, only the first $3 \mathrm{~s}$ of data, corresponding to ca. $9 \mathrm{~km}$, were decoded and processed. For the VIBSIST data of the ByxtjärnLiten and Liten-Dammån profiles, decoding was performed following Park (1996) and Cosma and Enescu (2001). A total of 400-500 hits per source point were stacked together to generate seismograms with a high $S / N$ ratio. For the data acquired with the weight drop source along the Sällsjö and Dammån-Hallen profiles, the normally eight hits per source location were stacked together to similarly enhance the $S / N$ ratio of the seismograms. The corresponding seismograms were then used as input to a standard seismic processing package.

The vertical component data from the three-component wireless receivers used in the Liten-Dammån profile were extracted and merged with the one-component receivers. Noisy traces from bad source points (e.g., due to bad weather conditions, bad ground coupling) and receivers (e.g., due to bad ground coupling, instrument malfunction, environmental noise) were then removed prior to subsequent processing.
A smoothly curved crooked common midpoint (CMP) line, in this paper used interchangeably with common depth point (CDP), was defined for the Byxtjärn-Liten and Dammån-Hallen profiles to minimize the number of missing traces while still following the acquisition line as closely as possible. Many of the structures in the area are subhorizontal with a slight dip in the direction of acquisition. Therefore, it is possible (as shown below) to stack the midpoint traces of the Sällsjö profile, despite their far offset, together with those of the Liten-Dammån profile onto a straight CDP line segment between the Byxtjärn-Liten and Dammån-Hallen profiles and obtain a seismic section with coherent reflections.

In general, the processing followed a standard processing sequence (Table 2). However, as the VIBSIST and weight drop data differed to some extent in their character due to the changed acquisition setups, pre-stack processing was performed separately for the different profiles. Examples of common source gathers from two locations along the profiles, before and after pre-stack processing, are shown in Fig. 4.

Thorough velocity analyses were performed in conjunction with both normal moveout (NMO) and dip moveout (DMO) corrections. DMO improved the coherency of the reflections along the Byxtjärn-Liten and Liten-Dammån profiles, but did not result in improved coherency along the Sällsjö and Dammån-Hallen profiles. The crookedness of the Sällsjö profile and the generally lower $S / N$ ratio along the Dammån-Hallen profile may explain the lack of improvement. Therefore, when the Liten-Dammån data were jointly 
processed with the Sällsjö data, as discussed below, no DMO was applied.

After processing the profiles separately, the Sällsjö and Liten-Dammån profiles were merged with the DammånHallen profile to fill in the gap. Given that separate processing of the Sällsjö profile showed generally subhorizontal reflections to be present below it, or reflections with NW dip (Fig. 5), the Sällsjö data and part of the Liten-Dammån data were projected onto a straight CDP processing line (Fig. 2). Likewise, the southeasterly part of the Liten-Dammån data were combined with the Dammån-Hallen data and processed along a straight CDP line (Fig. 2). Inspection of Fig. 5 shows that this methodology is generally justified, even for the highly crooked Sällsjö profile. The general characteristics of the Liten-Dammån profile (Fig. 5a) are maintained in the merged section (Fig. 5c), while the projection of the data from the Sällsjö profile (Fig. 5b) fills in the gap due to the acquisition constraints. Although the details in the merged Liten-Dammån and Sällsjö section may not be accurate, the general structure in the area is well represented.

Once processed, the separate profiles were projected onto a single composite profile for interpretation and migration (Fig. 6). Since lateral variations in velocity are only minor, post-stack time migration using a Stolt algorithm (Stolt, 1978) was used. The decision to stack both the LitenDammån and Sällsjö profiles on the same straight CDP line parallel with the dip direction is also favorable for 2D migration as this ensures that structures are moved to a more representative subsurface location. The migrated sections were finally time-to-depth converted to generate seismic sections suitable for geological interpretation. A velocity function based on the velocity analyses performed was smoothed to reduce the effects of local lateral variations, despite these being minimal, and used for the depth conversion. Figure $6 \mathrm{~b}$ shows the section from Fig. 6a after migration and time-todepth conversion.

\section{Discussion}

The interpretation of the Byxtjärn-Liten profile by Hedin et al. (2012) showed that the high-grade Seve Nappe Complex corresponds to a highly reflective unit, with a gently west-dipping eastern boundary in the vicinity of Undersåker (CDP 1200 in Fig. 6b), confirming previous evidence from the CCT profiling (Palm et al., 1991) in western Jämtland. Beneath and to the east of the Seve Nappe Complex, a transparent unit (ca. $1 \mathrm{~km}$ thick) is probably dominated by Ordovician turbidites, and underlain stratigraphically by thin limestones and Cambrian alum shales. More flat-lying reflections are present below these folded low-grade metasediments of the Lower Allochthon. The sole thrust was interpreted to be about $4.5 \mathrm{~km}$ below the exposed Seve Nappe Complex at Byxtjärn and to shallow eastwards to about $2.5 \mathrm{~km}$ in the vicinity of Liten, at CDP 3100 (Hedin et al., 2012). However, relationships to the Jämtlandian décollement were un- certain due to lack of a continuous profile to the Caledonian front and ambiguities in the interpretation of the older CCT profile, where the uppermost crust is not so well imaged. The new composite profile (CSP) presented here (Fig. 7) provides additional constraints on the structure, but a unique interpretation is still not possible. Below, we provide some general remarks on the CSP section and the relevance of other geophysical data for its interpretation. We then discuss interpretations of the seismic data, related to both a shallow Jämtlandian décollement, and a deeper sole thrust than the one presented in Hedin et al. (2012). Finally, we discuss two possible locations for the COSC-2 borehole.

\subsection{General characteristics of the COSC composite seismic profile (CSP)}

Both the VIBSIST source and weight drop source generated enough energy to allow the seismic waves to penetrate to at least $9 \mathrm{~km}$ depth (Fig. 5). A direct comparison of the sources is not possible since the profile locations, acquisition geometries, and the ambient noise conditions were not the same. In general, the VIBSIST source provided higher $S / N$ data than the weight drop source (compare Fig. 5a to Fig. 5b). However, merging of the two data sets generates a section which allows a clear correlation between reflections northwest and southeast of the gap on the Liten-Dammån profile (Fig. 5c). In particular, after merging, it is clear that the subhorizontal reflection at $0.7 \mathrm{~s}$ southeast of the gap (to the right of CDP 900 in Fig. 5c) is not connected to the two reflections at 0.4 to $0.6 \mathrm{~s}$ northwest of the gap (to the left of CDP 350 in Fig. 5c). Furthermore, the two west-dipping reflections at about 1 and $2 \mathrm{~s}$ (at CDP 1100, Fig. 5a), respectively, southeast of the gap appear to be connected to the subhorizontal reflections at 1.8 and $2.6 \mathrm{~s}$ northwest of the gap (Fig. 5a). Note that these reflections are better imaged on the Sällsjö profile with the weight drop source than on the Liten-Dammån profile with the VIBSIST source (compare Fig. 5a with Fig. 5b at CDP 100 to 300).

The entire composite profile (Fig. 7) shows generally subhorizontal reflections in the uppermost $2 \mathrm{~km}$. Below this depth the reflections are mainly northwest-dipping, but with some subhorizontal reflections. An exception is the patchy highly reflective zone in the upper $2 \mathrm{~km}$ in the CSP interval from CDP 100 to CDP 1200, which characterizes the Seve Nappe Complex. The west-dipping nature of this boundary is clearly defined from CDP 1100 to CDP 900, but the boundary becomes more diffuse below the central parts of the reflective zone. The diffuse nature of this boundary at depth was verified by the drilling of the COSC-1 borehole to $2.5 \mathrm{~km}$ (Lorenz et al., 2015) and the limited 3-D seismic survey that was acquired after drilling was completed (Hedin et al., 2016). Between CDP 1100 and 4600 along the CSP, distinct, northwest-dipping reflections are present, some of which can potentially be traced from $7 \mathrm{~km}$ depth to the subhorizontal reflections between 1 and $2 \mathrm{~km}$ depth. These dip- 
Table 2. Processing steps and parameters for the Byxtjärn-Liten profile (BL, 2010), Liten-Dammån profile (LD, 2011), Sällsjö profile (S, 2014), and Dammån-Hallen profile (DH, 2014). BL, S + LD , and DH were merged prior to migration to form the composite COSC seismic profile, CSP.

\begin{tabular}{|c|c|c|c|c|}
\hline BL (2010) & LD (2011) & S (2014) & $\mathrm{S}+\mathrm{LD}$ & DH (2014) \\
\hline Decoding of & Decoding of & Stacking of & & Stacking of \\
\hline VIBSIST data & VIBSIST data & weight drop gathers & & weight drop gathers \\
\hline Manual trace edits & Manual trace edits & Manual trace edits & & Manual trace edits \\
\hline Floating datum statics & Floating datum statics & Floating datum statics & & Floating datum statics \\
\hline $\begin{array}{l}\text { Refraction static } \\
\text { corrections }\end{array}$ & $\begin{array}{l}\text { Refraction static } \\
\text { corrections }\end{array}$ & $\begin{array}{l}\text { Refraction static } \\
\text { corrections }\end{array}$ & Data merged & $\begin{array}{l}\text { Refraction static } \\
\text { corrections }\end{array}$ \\
\hline Frontmute & Frontmute & & Surgical mute & Frontmute \& surgical mute \\
\hline $\begin{array}{l}\text { Spherical divergence } \\
\text { compensation }\end{array}$ & $\begin{array}{l}\text { Spherical divergence } \\
\text { compensation }\end{array}$ & $\begin{array}{l}\text { Spherical divergence } \\
\text { compensation }\end{array}$ & $\begin{array}{l}\text { Spherical divergence } \\
\text { compensation }\end{array}$ & $\begin{array}{l}\text { Spherical divergence } \\
\text { compensation }\end{array}$ \\
\hline Trace balancing & Trace balancing & Trace balancing & Trace balancing & Trace balancing \\
\hline \multirow[t]{2}{*}{ Wiener deconvolution } & Wiener deconvolution & Spectral equalization & Wiener deconvolution & Wiener deconvolution \\
\hline & & Notch filter $(50 \pm 2 \mathrm{~Hz})$ & Notch filter $(50 \pm 2 \mathrm{~Hz})$ & Notch filter $(50 \pm 2 \mathrm{~Hz})$ \\
\hline Band pass filter & Band pass filter & Band pass filter & Band pass filter & Band pass filter \\
\hline $0-1 \mathrm{~s}$ & $0-0.5 \mathrm{~s}$ & $0-0.5 \mathrm{~s}$ & $0-1 \mathrm{~s}$ & $0-1 \mathrm{~s}$ \\
\hline $25-50-80-120 \mathrm{~Hz}$ & $25-50-100-150 \mathrm{~Hz}$ & $25-50-100-150 \mathrm{~Hz}$ & $25-50-100-150 \mathrm{~Hz}$ & $25-50-100-150 \mathrm{~Hz}$ \\
\hline $1.25-3 \mathrm{~s}$ & $0.75-1.25 \mathrm{~s}$ & $0.75-1.25 \mathrm{~s}$ & $1.25-1.75 \mathrm{~s}$ & $1.25-1.75 \mathrm{~s}$ \\
\hline \multirow[t]{3}{*}{$20-40-80-120 \mathrm{~Hz}$} & $20-40-90-135 \mathrm{~Hz}$ & $20-40-90-135 \mathrm{~Hz}$ & $20-40-90-135 \mathrm{~Hz}$ & $20-40-90-135 \mathrm{~Hz}$ \\
\hline & $1.75-3 \mathrm{~s}$ & $1.75-3 \mathrm{~s}$ & $2.25-3 \mathrm{~s}$ & $2.25-3 \mathrm{~s}$ \\
\hline & $15-30-80-120 \mathrm{~Hz}$ & $15-30-80-120 \mathrm{~Hz}$ & $15-30-80-120 \mathrm{~Hz}$ & $15-30-80-120 \mathrm{~Hz}$ \\
\hline Airwave filter & Airwave filter & & & \\
\hline Median velocity filter & Median velocity filter & Median velocity filter & Median velocity filter & Median velocity filter \\
\hline $2200,3200 \mathrm{~m} \mathrm{~s}^{-1}$ & $2200,3200 \mathrm{~ms}^{-1}$ & $3100 \mathrm{~m} \mathrm{~s}^{-1}$ & $1700,3100 \mathrm{~m} \mathrm{~s}^{-1}$ & $1700,3100 \mathrm{~ms}^{-1}$ \\
\hline AGC (200 ms) & AGC (300 ms) & & AGC (200 ms) & AGC (500 ms) \\
\hline $\begin{array}{l}\text { Residual static } \\
\text { corrections }\end{array}$ & $\begin{array}{l}\text { Residual static } \\
\text { corrections }\end{array}$ & $\begin{array}{l}\text { Residual static } \\
\text { corrections }\end{array}$ & $\begin{array}{l}\text { Residual static } \\
\text { corrections }\end{array}$ & $\begin{array}{l}\text { Residual static } \\
\text { corrections }\end{array}$ \\
\hline $\begin{array}{l}\text { DMO \& NMO } \\
\text { correction }\end{array}$ & $\begin{array}{l}\text { DMO \& NMO } \\
\text { correction }\end{array}$ & NMO correction & NMO correction & NMO correction \\
\hline CDP stacking & CDP stacking & CDP stacking & CDP stacking & CDP stacking \\
\hline \multirow{3}{*}{$\begin{array}{l}\text { Coherency filtering } \\
\text { (FX deconvolution) }\end{array}$} & Coherency filtering & Coherency filtering & Coherency filtering & Coherency filtering \\
\hline & (FX deconvolution) & (FX deconvolution) & (FX deconvolution) & (FX deconvolution) \\
\hline & & Zeromute & Zeromute & Zeromute \\
\hline FK filter & FK filter & & FK filter & \\
\hline Stolt migration & & & Stolt migration & Stolt migration \\
\hline Time-to-depth & & & Time-to-depth & Time-to-depth \\
\hline conversion & & & conversion & conversion \\
\hline
\end{tabular}

ping reflections appear to merge into the overlying shallower subhorizontal reflections. Similar dipping reflections were also observed on the CCT profile (Juhojuntti et al., 2001) and some of them can be correlated to the CSP by their geometrical patterns in spite of the two profiles being separated by about $20 \mathrm{~km}$. The source of these dipping reflections has previously been discussed (Palm et al., 1991; Juhojuntti et al., 2001; Hedin et al., 2012). Deformation zones, dolerite sheets, or a combination of the two were considered likely candidates. At the southeastern end of the CSP (CDP 4600 to 5500) the data quality deteriorates significantly (Fig. 6) due to the presence of an up to $60 \mathrm{~m}$ thick sequence of unconsolidated Quaternary sediments, which severely attenuate the signals and make it difficult to track the reflections beneath them. However, the shallowest subhorizontal reflection can be traced to about $0.5 \mathrm{~km}$ depth at the southeasternmost end of the profile, as can the northwest-dipping reflection at about $6 \mathrm{~km}$. The lack of clear reflections in between these two is due to poor $S / N$. This reasoning is verified by a comparison with the CCT profile (Fig. 8) on which there are clear northwest-dipping reflections in the equivalent depth interval and in the same structural position along the profile. Note that the Dammån-Hallen profile was not extended further to the southeast due to permitting issues. Even if it had been possible, the thick sequence of unconsolidated sediments, also partly present to the southeast, would probably have made it difficult to acquire good data.

Two important relationships need to be defined - the depth and character of the Jämtlandian décollement, and also the thickness and character of the underlying basement that has 

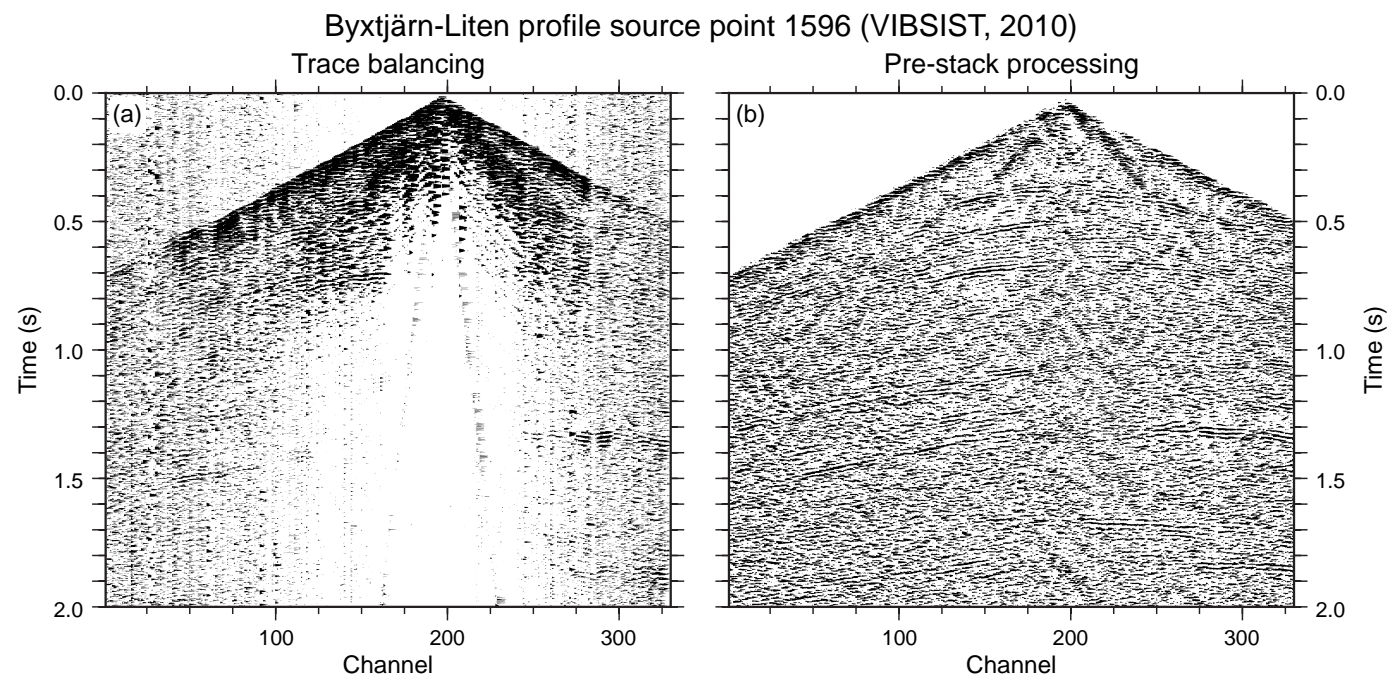

Sällsjö profile source point 9 (weight drop, 2014)
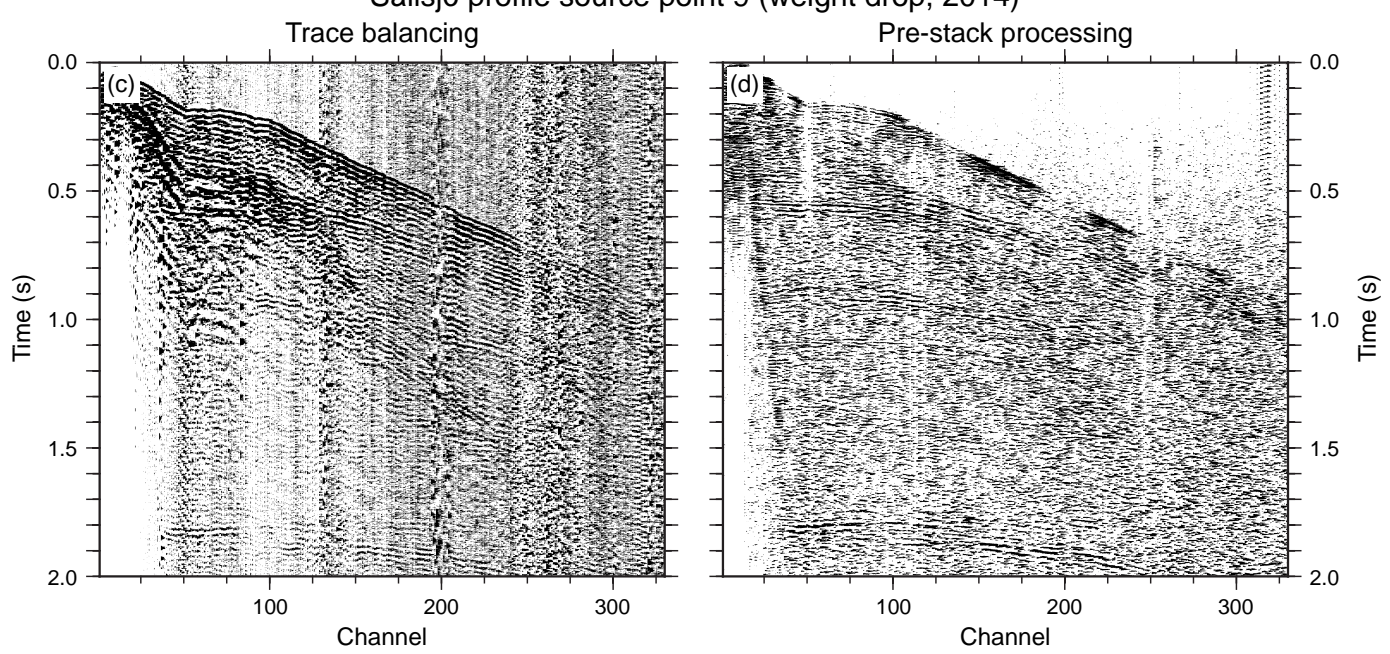

Figure 4. Two examples of source gathers before and after processing. (a) VIBSIST source gather from the Byxtjärn-Liten profile from the south shore of Lake Liten (Fig. 2) with only trace balancing applied. (b) The same source gather as in (a) after processing. (c) Weight-drop source gather from the Sällsjö profile from the eastern end of Lake Liten with only trace balancing applied. (d) The same source gather as in (c) after processing.

been influenced by Caledonian deformation. The drilling in the Myrviken area, southeast of the CSP, clearly defined the Jämtlandian décollement, where Cambro-Ordovician sedimentary rocks are thrust over a thin autochthonous sedimentary cover and the underlying basement shows no evidence of Caledonian deformation. If the geometry of the Jämtlandian décollement in this area (Figs. 2 and 3) is projected into the southeastern end of the CSP, it would be expected to be found at a depth of about $500 \mathrm{~m}$, coinciding with the subhorizontal reflection found at this depth on the southeastern end of the composite section (Fig. 7). This reflection is not continuous northwestwards to CDP 4800, but rather irregular, perhaps due to the variable quality of the data that was acquired over the thick Quaternary sediments. However, we interpret the reflection at about $0.7 \mathrm{~km}$ depth at CDP 4800 along the CSP
(Fig. 7) to represent the Jämtlandian décollement that was drilled further southeast in the Myrviken area. This reflection can be fairly reliably traced along the CSP to CDP 3300 . Here, it is unclear if the décollement continues along the uppermost reflection at $1.2 \mathrm{~km}$ depth to CDP 2900 or along the lower one at $1.7 \mathrm{~km}$ depth at CDP 2900. Several lines of evidence indicate that the shallower reflection probably represents the Jämtlandian décollement. On the CCT profile, to the north, the Jämtlandian décollement was interpreted to be at about $1 \mathrm{~km}$ depth at an equivalent distance from the Caledonian front. Interpretation of the depth to magnetic basement based on the slope of the magnetic anomalies (using the standard Peter's method; see e.g., Reynolds, 2011) along the composite profile (Fig. 7) gives values of about 1.3 and $1 \mathrm{~km}$ at CDPs 3100 and 4100 , respectively. Note that an alter- 

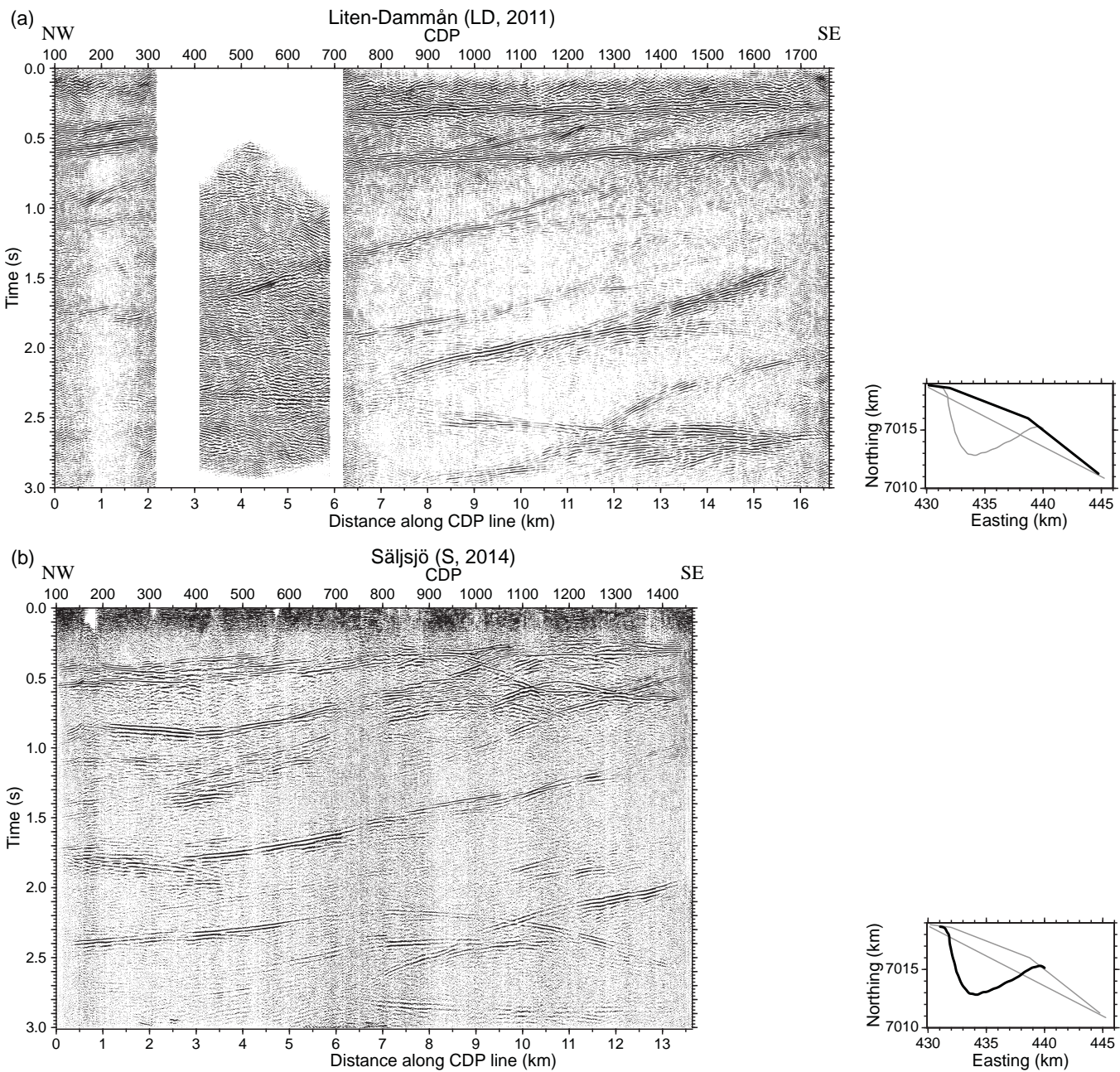

SE
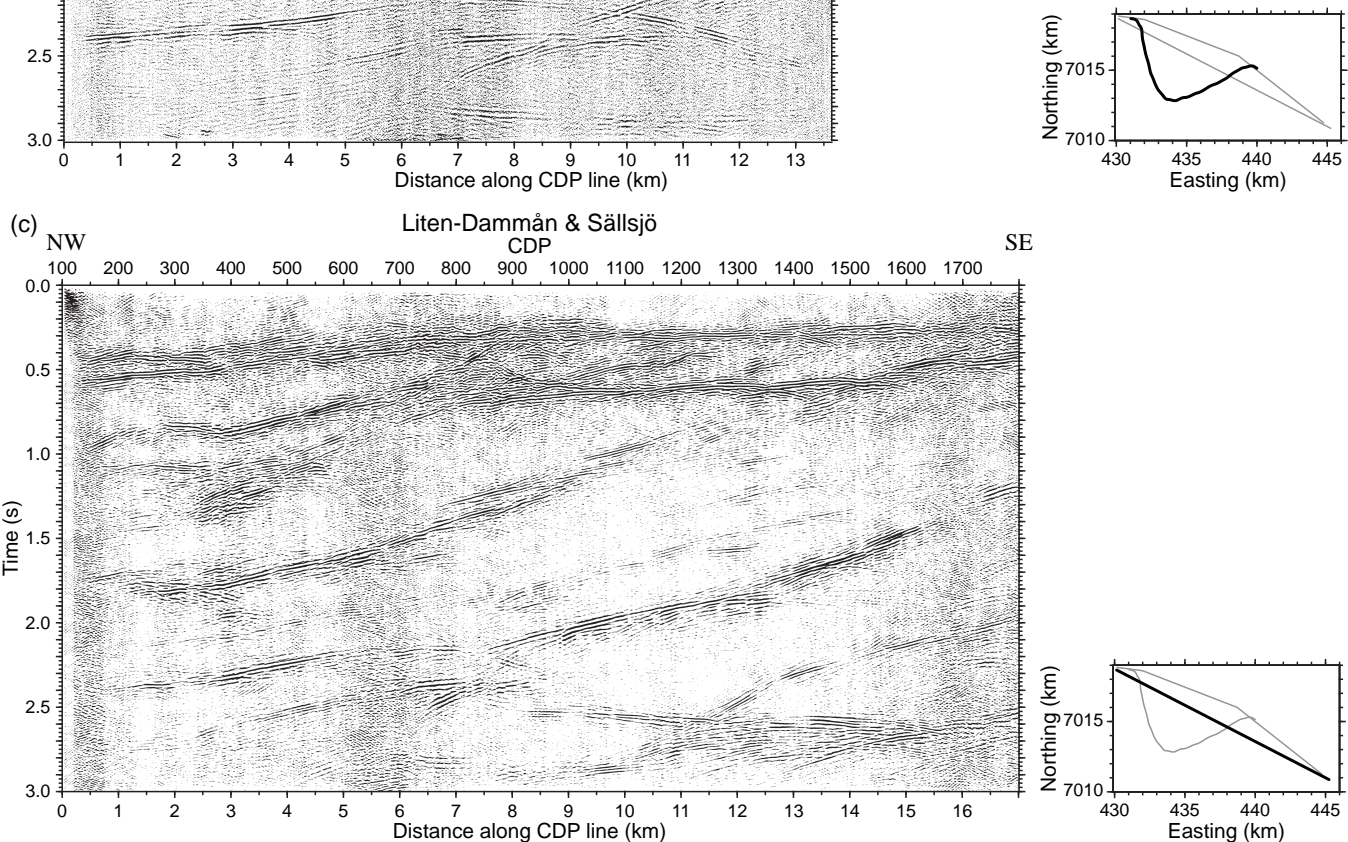

SE

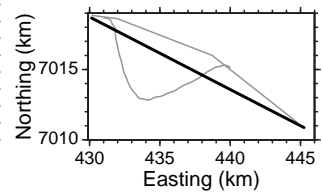

Figure 5. (a) Stacked section from the Liten-Dammån profile acquired in 2011 with the VIBSIST source. (b) Stacked section from the Sällsjö profile acquired in 2014 with the weight drop source. (c) Data from the Liten-Dammån and Sällsjö profiles processed together and stacked. The plan view maps show the three CDP stacking lines used, with the thick black line indicating the CDP stacking line corresponding to the section shown in the same panel. Panels (a) and (c) follow similar CDP stacking lines, while (b) follows a highly crooked CDP stacking line. 


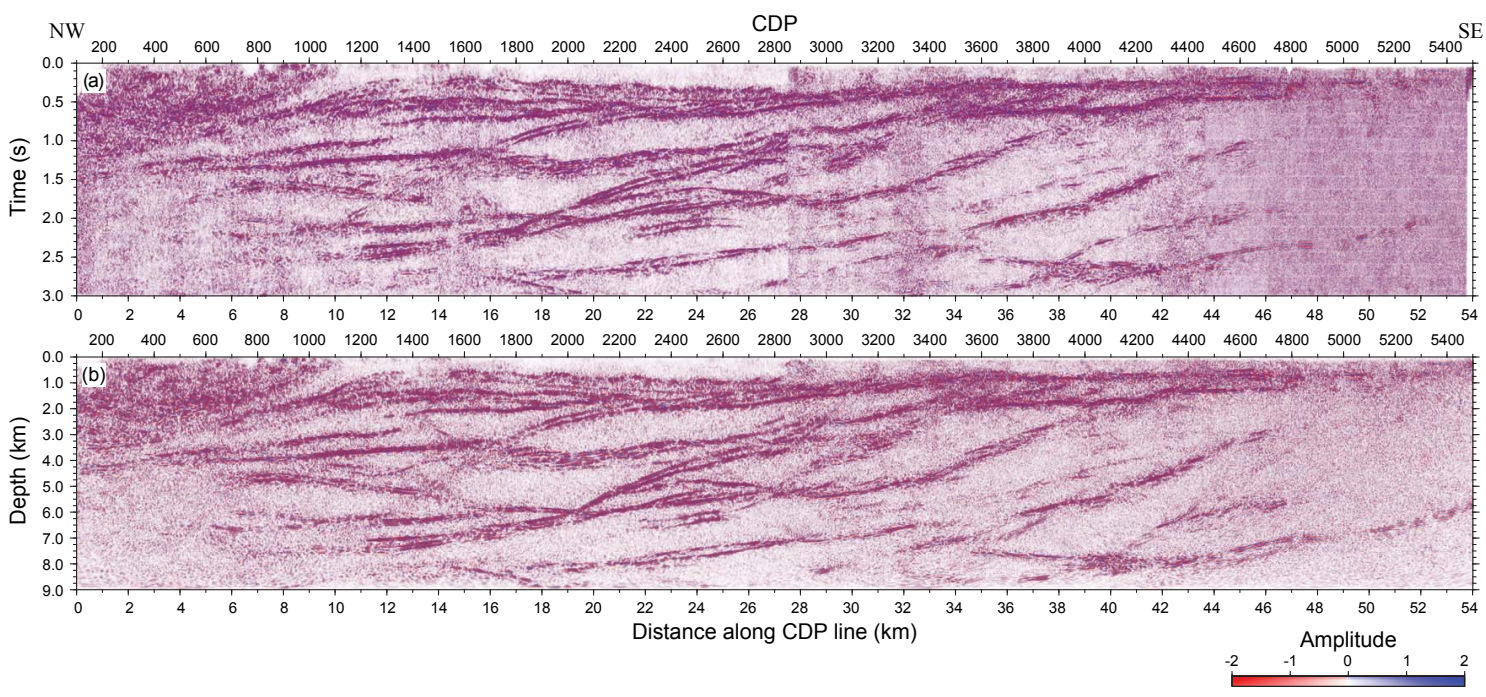

Figure 6. (a) Composite stacked section of the CSP. (b) Migrated and depth converted version of (a). The CDP stacking line is shown in Fig. 2 with CDP numbers marked on the map. East of CDP 2850 the weight drop source was employed.
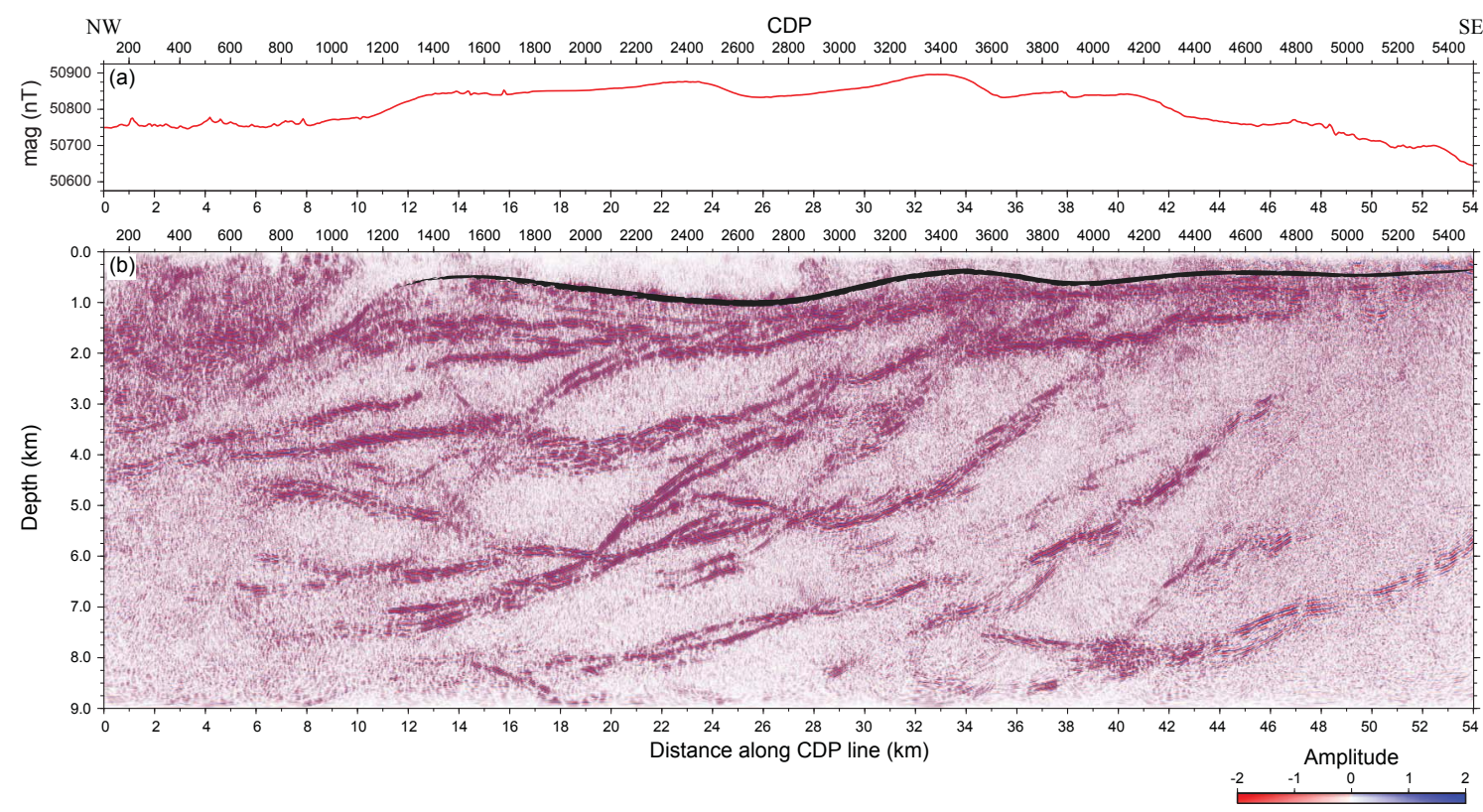

Figure 7. (a) Total magnetic field along the CSP. The anomalies at about CDP 1800, 3100, and 4100 can be interpreted as due to variations in the magnetic basement at depths of 1.3, 1.3, and $1.0 \mathrm{~km}$, respectively. (b) Migrated and depth converted stack from Fig. 6 shown at a vertical exaggeration of $2: 1$. The black line marks the depth to the highly conductive layer from MT data as mapped by Yan et al. (2016). An excellent correspondence exists between the base of the uppermost seismically transparent zone and the mapped conductor. Therefore, the onset of reflectivity below the transparent zone is interpreted to represent the top of the uppermost alum shale. Magnetic data are courtesy of the Geological Survey of Sweden (SGU).

native interpretation for the Jämtlandian décollement is that it deepens already at CDP 5200 down to $1 \mathrm{~km}$ depth. This alternative will be discussed later in the paper.

The new magnetotelluric (MT) survey along the profile (Yan et al., 2016) provides evidence of a gently undulating surface of the prominent uppermost conductive layer, shown in Fig. 7, this being located at ca. $500 \mathrm{~m}$ at the eastern end of the CSP, sinking to $600 \mathrm{~m}$ at CDP 3800 , rising to $400 \mathrm{~m}$ at CDP 3500, sinking again to $1100 \mathrm{~m}$ at CDP 2700, and then rising again at CDP 1600 to $600 \mathrm{~m}$, before dipping west again beneath the Seve Nappe Complex, west of Undersåker. This undulation fits well with the inferred location of the axes of the synforms and antiforms that are located in the vicinity to the north and south of the CSP line. The highly conductive 

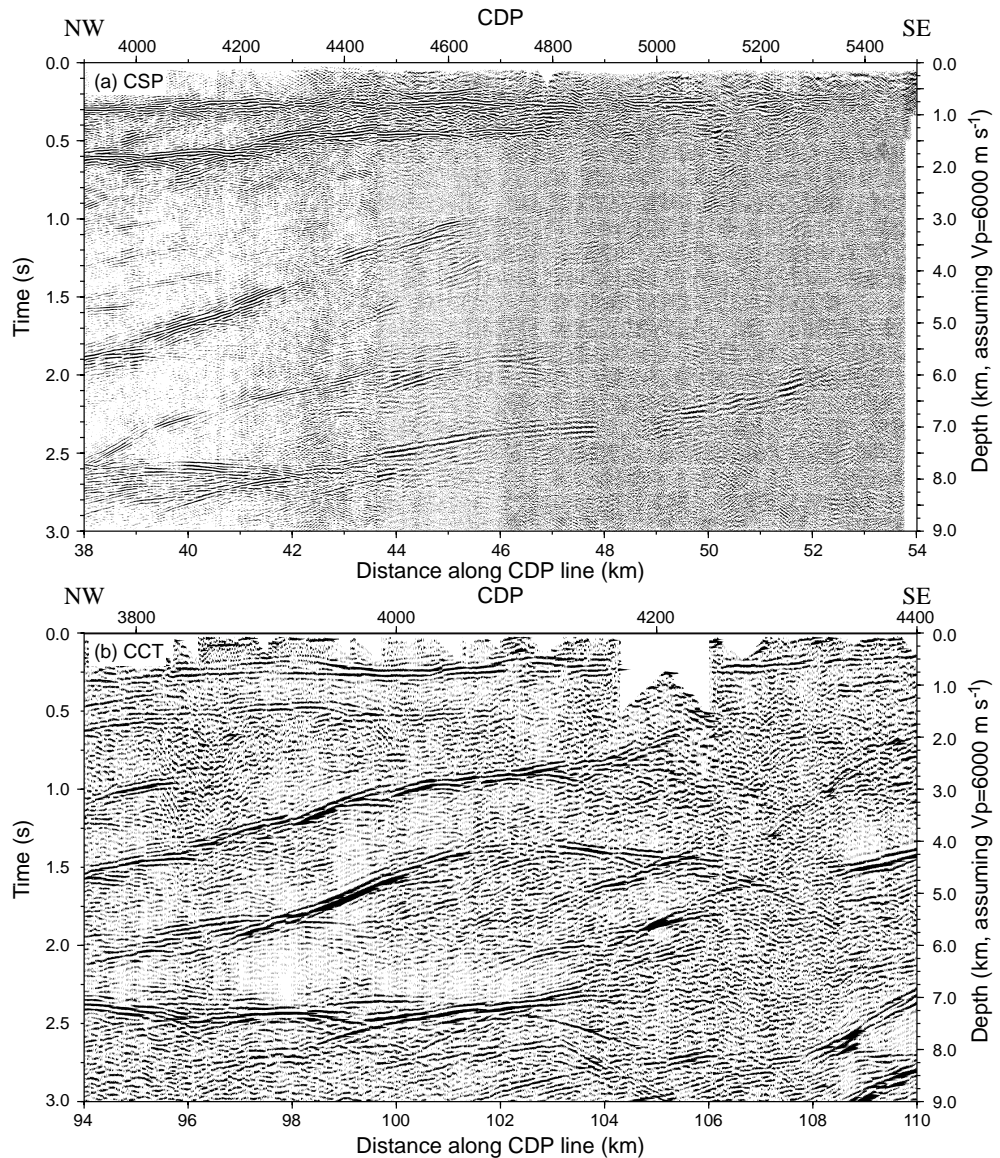

Figure 8. Sections of the CSP (top) and CCT profile (bottom) over approximately the same structural location. The three prominent reflective zones between 1 and $3 \mathrm{~s}$ on the western halves of the profiles are interpreted to represent the same structures. The transparent zone between 0.5 and $2 \mathrm{~s}$ on the eastern half of the CSP is interpreted as due to poor $S / N$ because of the thick sequence of loose sediments at the surface along this portion of the profile. Although data quality is variable at the equivalent location on the CCT profile, clear reflections are present between 0.5 and $2 \mathrm{~s}$. It is likely that with better quality data, clear reflections would also be observed on the eastern half of the CSP between 0.5 and $2 \mathrm{~s}$.

layer is interpreted to represent the uppermost alum shales. It is therefore possible that the Jämtlandian décollement could be at a depth of about $1.5 \mathrm{~km}$ at CDP 2900 along the CSP and, if so, that it shallows to less than $1 \mathrm{~km}$ further west at CDP 1500 (Fig. 7) and then deepens at CDP 1300, below the Seve Nappe Complex.

All alternative interpretations accept the evidence for shallow décollements and require a substantially deeper location for the Caledonian sole thrust (e.g., Hedin et al., 2012). In both the Oviksfjällen and Olden antiforms, located to the south and north of the CSP profile, respectively, and apparently crossing it at ca. CDP 3300-3500, there is evidence of substantial shortening, with a quartzite-dominated thrust stack in Oviksfjällen and much internal basement deformation in Olden. The Olden Antiform is of particular interest because it contains an upper part of allochthonous basement (Gee, 1980; Robinson et al., 2014) thrust over the CambroSilurian sedimentary rocks of the Jämtland Supergroup. The extent to which sedimentary rocks of the Lower Allochthon might be represented at deeper structural levels than those exposed in the Olden and Oviksfjällen antiforms is, at present, impossible to say; MT methods have difficulty in detecting any features below a strong conductor like the alum shales that is so well defined in the overlying décollement levels. Furthermore, the Oviksfjällen and Olden antiforms do not have a strong magnetic signature. The depth extent of the basement reflectivity is on the order of $10 \mathrm{~km}$ and presumably originates in magnetic basement; therefore, it is not clear how these antiforms can be linked to the origin of the basement reflections.

\subsection{Interpretations}

In the following section we discuss alternative interpretations along the CSP. The first one, based on Hedin et al. (2012), focuses on the sole thrust and considers even deeper structural levels for the Caledonian deformation. The second consid- 


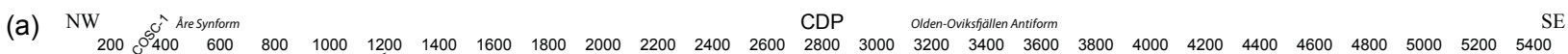

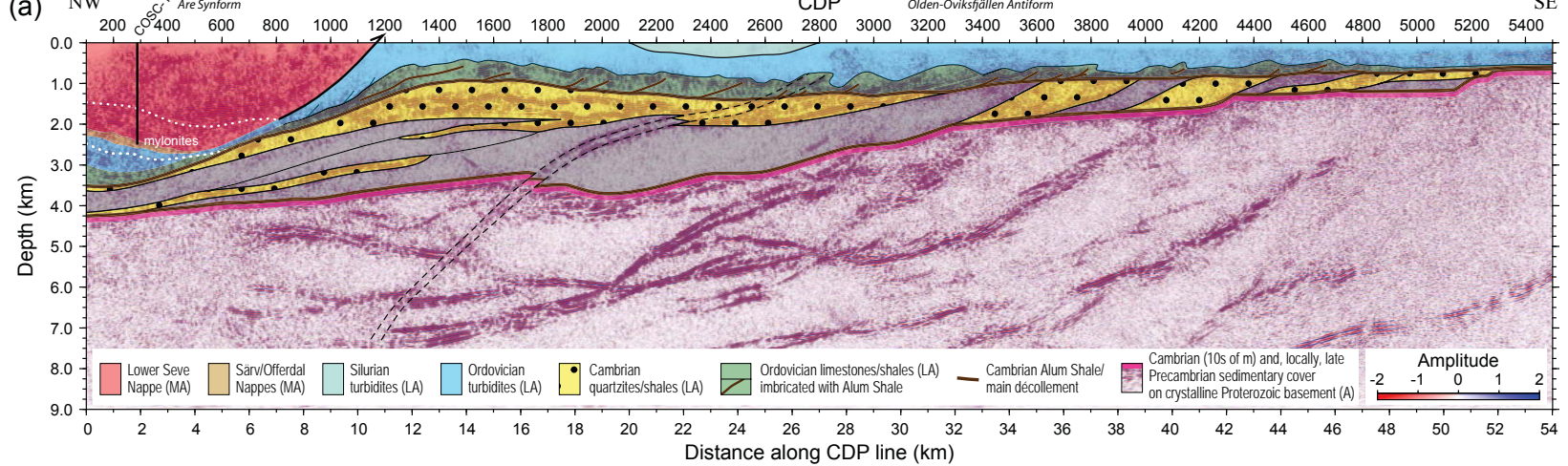

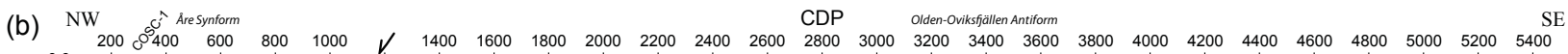

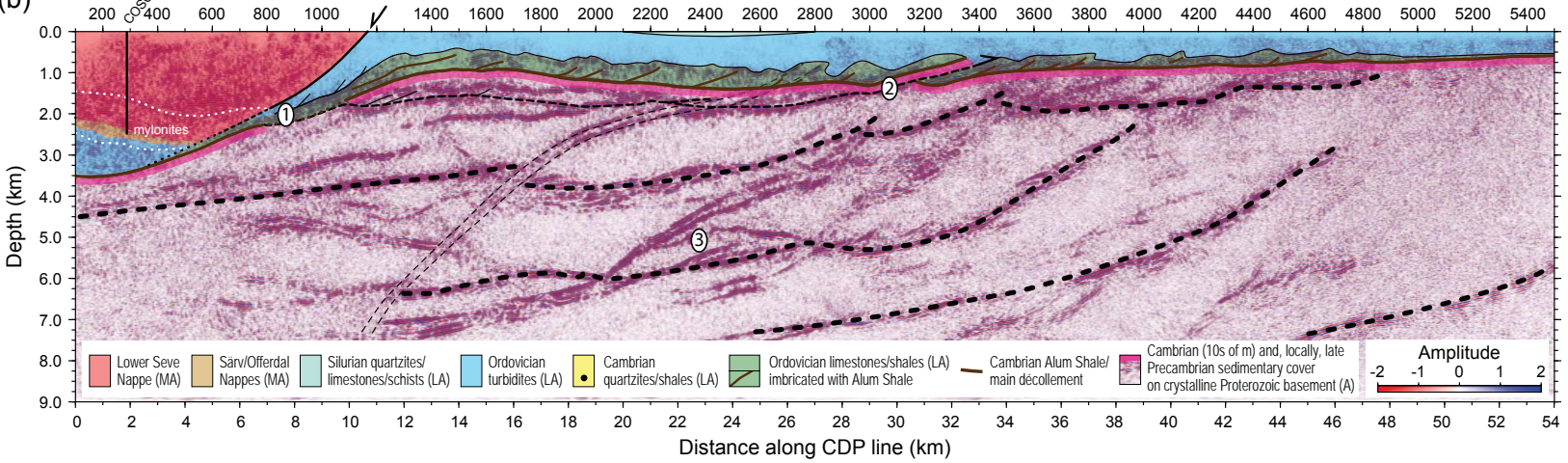

Figure 9. Interpretations of the CSP data. In (a) the focus is on the sole thrust. The interpretation west of CDP 2800 is the same as in Hedin et al. (2012) and shows significant basement involved thrusting; farther east, the sole thrust is shown to ramp up to join the Jämtlandian décollement near the thrust front. In (b) the Jämtlandian décollement is shown to dip very gently westwards, lying only a few hundreds of meters below the top of the alum shales, as interpreted from the CSP and the MT data. A second level of detachment may exist in the shallow basement reflectors below CDP 1000 to 3200. Numbers (1), (2), and (3) are referenced in the text.

ers the Jämtlandian décollement in relation to the location of the uppermost alum shales and the underlying flat-lying reflectors in the upper $2 \mathrm{~km}$ of the crust, in line with the interpretations presented in Juhojuntti et al. (2001) and Korja et al. (2008). Figure 9 illustrates these interpretations.

In Figure 9a we present the section of Hedin et al. (2012) up to CDP 2900 (the easternmost extent of the ByxtjärnLiten profile); further east we define a consistent prolongation within the CSP. The sole thrust, in western parts at about $4 \mathrm{~km}$ depth, rises eastwards to the flat reflectors at about $2 \mathrm{~km}$ depth between CDP 3400 and 4200. It then ramps up to ca. $1.5 \mathrm{~km}$ and continues at this level to CDP 5100. Here it ramps up again to ca. $500 \mathrm{~m}$ and extends eastwards into the frontal décollement in the Myrviken area. The flat sections between CDP 3400 and 5100 both underlie hangingwall west-dipping reflections, which suggests imbrication. The interpretation in Fig. 9a is based on the geology of the Oviksfjällen Antiform where the early Cambrian (to Ediacaran) quartzites dominate, but include some slices of Precambrian volcanic rocks, particularly in the eastern limb of the structure. Even deeper Caledonian deformation cannot be excluded. In this case, the sole thrust would extend from the frontal ramp at CDP 5100-5200 via a flat to CDP 4400, and from there downwards along prominent west-dipping reflections to a flat at ca. $5 \mathrm{~km}$ depth beneath CDP 3000 where it continues westwards along more gently dipping reflections. This alternative would pass into the flat reflectors beneath the Mullfjället Antiform at ca. $7 \mathrm{~km}$ depth (Palm et al., 1991) and then perhaps extend beneath the Skardöra Antiform at similar (Hurich et al., 1989) or even greater depths (Gee, 1988). Both these deep sole thrust interpretations require that the shallow Rätan-type basement beneath CDP 3400 and farther east, as suggested by the magnetic data, is allochthonous on top of a basement with similar characteristics.

The interpretation, presented in Fig. 9b, concentrates on the Jämtlandian décollement beneath the Jämtlandian Nappes and the new geophysical and geological evidence relevant to the uppermost $2 \mathrm{~km}$ of the crust. The characteristic feature here is the shallow level of the décollement to the southeast of CDP 1400 and the significant deepening westwards below the Åre Synform. The Jämtlandian décollement is probably accommodated within, or in close proximity to, the highly organic-rich Cambrian alum shales that constitute a weak horizon at, or near, the base of the Early Pale- 

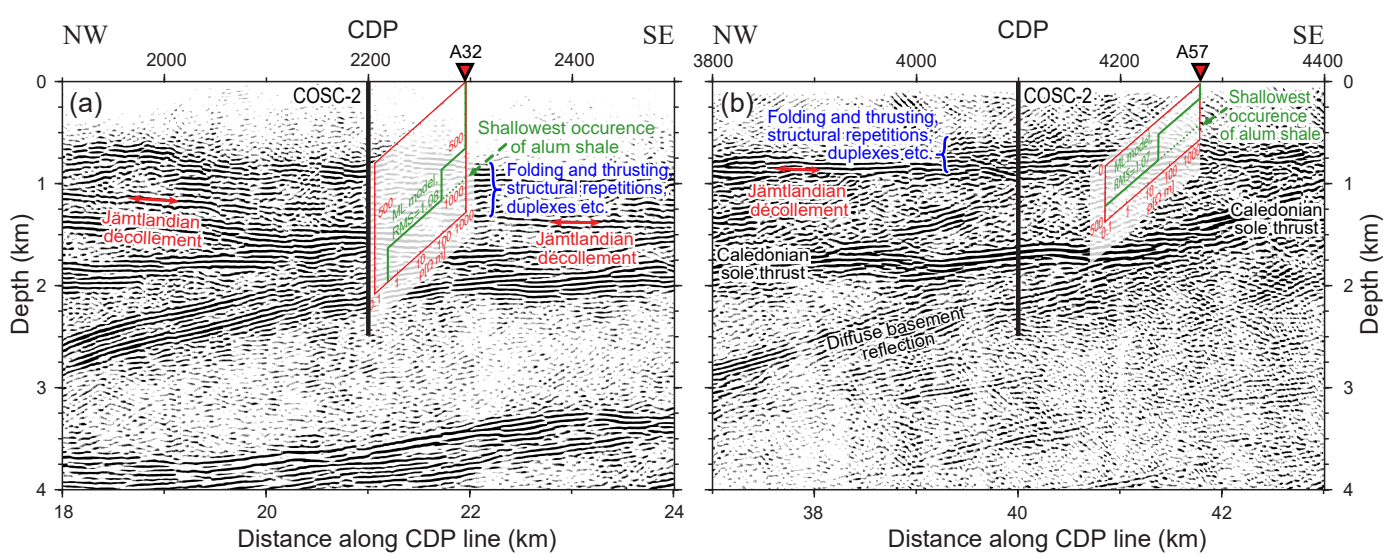

Figure 10. (a) Option 1 for the COSC-2 borehole. Here, the Jämtlandian décollement would be penetrated at about 1.3-1.5 km depth, if the interpretation in Fig. $9 \mathrm{~b}$ is correct. Logistically, it is easier to place the borehole about $1 \mathrm{~km}$ to the east. Even at this location, two or three Precambrian reflectors would be penetrated. (b) In option 2 for the COSC-2 borehole, the Jämtlandian décollement would be drilled at about $500 \mathrm{~m}$ depth. The structure beneath the Jämtlandian décollement, down to about $1600 \mathrm{~m}$, is dominated by a duplex, probably consisting of sedimentary formations and basement-derived imbricates. The basal thrust of the duplex is inferred to coincide with the Caledonian sole thrust. The conductivity profiles shown in the figures are placed at the locations of the MT stations that the inversions were performed for. In (a) the uppermost alum shale would be penetrated at about $900 \mathrm{~m}$ depth and in (b) it would be penetrated at about $400 \mathrm{~m}$ depth.

ozoic Baltoscandian sedimentary succession. In some areas, up to some tens of meters of Ediacaran to lower Cambrian quartzites separate the alum shales from the underlying basement of the Fennoscandian Shield (Andersson et al., 1985). This unit may be locally absent because of the original basement topography, or stripping by the overlying thrust; alternatively, it may be repeated several times within the décollement zone.

The new magnetotelluric (MT) data indicate the presence of a good conductor at ca. $1000 \mathrm{~m}$ at CDP 2200 and just below $500 \mathrm{~m}$ at CDP 4100 (Fig. 10). Below these depths, the reflection pattern in the seismic profile indicates imbricate thrusting above a detachment horizon. The latter is interpreted as the original, stratigraphic position of the alum shales, which host the Jämtlandian décollement. Within the imbricates, alum shale is brought to a shallower level as indicated by the MT data. This relationship is similar to that observed close to the present Caledonian front (Fig. 3; Gee et al., 1982; Andersson et al., 1985), where successions of alum shales with overlying Lower Ordovician limestones and shales and, further west, underlying quartzites are stacked to several times the original stratigraphic thickness.

\subsection{Relationships between the Jämtlandian décollement and mylonites in the Lower Seve Nappe}

Close to the northwestern end of the profile, in the Åre Synform, the $2.5 \mathrm{~km}$ deep COSC-1 drill hole provides control on the Lower Seve Nappe. At ca. $1700 \mathrm{~m}$, the borehole enters a mylonite zone, representing a major thrust at the base of the Seve Nappe Complex. This zone extends to the bottom of the borehole, but a transition to rocks of lower meta- morphic grade, possibly from the Särv or Offerdal nappes, occurs at ca. $2350 \mathrm{~m}$ (Lorenz et al., 2015). Local 3-D reflection seismics at the drill site (Hedin et al., 2016) and a vertical seismic profile (VSP) survey in the drill hole (Krauß et al., 2015) suggest that the base of the thrust zone is located about $200 \mathrm{~m}$ below the bottom of the drill hole. The Särv and Offerdal Nappes are not continuous in the Åre area, but thin and pinch out towards the northeast somewhere below the Åre Synform, as indicated in Fig. 9b. However, farther east the Särv Nappe is present in a klippe (Strömberg et al. 1984). It is also remarkable that east of the Åre Synform, the fault zone that separates the Lower Seve Nappe from the Lower Allochthon is very narrow (north of CDP 1150), i.e., significantly different from the mylonite zone observed in the COSC-1 borehole. The contact observed at the surface is most likely a W-dipping normal fault that places the Lower Seve Nappe against the Lower Allochthon and, thus, cuts out the tectonostratigraphy in between. Similar relationships across faults were reported in the area west of Mullfjället in Sweden, and Skardöra in Norway (Sjöström et al., 1991, Braathen et al., 2000). Below $2 \mathrm{~km}$ depth, the normal fault passes into a highly reflective zone above the interpreted Jämtlandian décollement, which it either cuts or merges into. The borders of the mylonite zone below the Åre Synform (dotted white lines in Fig. 9) trace along the reflectivity pattern eastwards towards location (1) in Fig. 9b, where also they merge into the above-mentioned NW-dipping highly reflective zone above the Jämtlandian décollement. East of location (1), a prominent shallow basement reflection can be traced subhorizontally towards location (2), where it offsets the overlying reflections and continues upwards towards the southeast (broken line in Fig. 9b). It is interpreted as a thrust 
fault that at location (2) cuts upwards through the Jämtlandian décollement into the alum shale and brings basement with overlying rocks closer to the surface. The position, CDP 3100 and 3500, corresponds well with the location of the Oviksfjällen Antiform, which about $10 \mathrm{~km}$ south of the seismic profile exposes Ediacaran-Cambrian quartzites in its core (Fig. 2). The nature of the reflectivity above this interpreted thrust fault is ambiguous. Possibly, it is similar to the basement reflections farther down. This would imply that the displacement along this particular reflector is a couple of kilometers, as indicated in Fig. 9b.

For the section of the CSP, we suggest the following geological scenario. The high-grade metamorphic Lower Seve Nappe has a comparatively long tectonothermal history with metamorphism and pegmatite intrusion as early as ca. $470 \mathrm{Ma}$ (Li et al., 2014). Its subsequent emplacement as part of the Seve Nappe Complex has caused the penetrative ductile deformation with high internal strain, including gneisses with mylonitic fabric. Thrusting continuously progressed eastwards with the whole nappe stack, including the underlying units of the Middle Allochthon and Lower Allochthon, translated farther towards the foreland on the Jämtlandian décollement in the alum shales.

After metamorphic conditions in the Lower Seve Nappe had decreased considerably, the ca. $1 \mathrm{~km}$ thick mylonite zone began to develop by continued or resumed movement along the Seve-Särv boundary. The age of the movement on the interpreted normal fault that separates the Lower Seve Nappe from the Lower Allochthon, east of the Åre Synform, is probably Early Devonian, as suggested by Gee et al. (1994) for the Röragen detachment where movement was inferred to have occurred while thrusting was still going on at depth beneath the Vigelen Antiform. This could explain why both the reflective pattern, which was related to the Seve mylonite zone in the COSC-1 drill hole, and the trace of the normal fault merge into a highly reflective zone that is directly overlying the Jämtlandian décollement at location (1) in Fig. 9b.

While nappe emplacement during Caledonian orogeny progressed towards the foreland, Baltica was successively underthrusting Laurentia. Thus, it is very likely that also the Baltican basement experienced an eastwards progressing deformation, most likely above a sole thrust and possibly reactivating existing structures in the Proterozoic basement. Major orogen-parallel folding (e.g., Åre Synform and Mullfjället Antiform) occurred above this sole thrust. In the CSP, at least some of the deep reflections (around location 3 in Fig. 9b) are thought to represent this basement deformation.

Additional evidence for some Caledonian deformation is found where reflections present below the interpreted Jämtlandian detachment appear to continue through it and offset the interpreted alum shales. Perhaps the best example of this is between CDPs 2600 and 2800 (Fig. 6) where the "double reflection" may offset the detachment and appears to have disturbed the overlying alum shales.
Scientific drilling at the COSC-2 site to $2.5 \mathrm{~km}$ will investigate and test the above scenario down into the shallow basement. It will sample at least one of the deep reflectors at its shallowest level and define its nature.

\subsection{Locating the COSC-2 borehole}

According to the COSC overall scientific targets, the COSC2 borehole will investigate the metamorphic and structural evolution from the Lower Allochthon down into the basement of the Fennoscandian Shield. Important questions to be answered by the drilling are as follows. (i) What is the nature of the Jämtlandian décollement and where is it located? (ii) Is the metamorphic grade inverted in the middle- to lowgrade greenschist facies sedimentary rocks? (iii) Were they heated from above? (iv) What lithologies and structures generate the reflections in the Precambrian basement? (v) What is the timing of deformation at these structural levels?

To reach these goals, the borehole should first drill the turbidites and limestones of the Lower Allochthon, penetrate the uppermost Cambrian alum shales, and then continue downwards in the zone of high reflectivity, probably with repetition of thin Ediacaran to Ordovician sedimentary cover (quartzites, alum shales, and limestones) and then through the Jämtlandian décollement into the Precambrian crystalline basement, sampling at least a $1 \mathrm{~km}$ section of the latter.

Two possible locations for the COSC-2 borehole have been identified on the composite profile (Fig. 10). Option 1 is located along the Byxtjärn-Liten profile at CDP 2200 (Fig. 10a). Assuming that the Jämtlandian décollement has been correctly identified in Fig. 9b, the borehole will penetrate four reflectors in the underlying basement between about 1.5 and $2.2 \mathrm{~km}$ depth. A drill hole in this location would investigate the imbricate thrusting above the Jämtlandian décollement, whether the inferred deeper (shallow basement) thrust between CDP 1100 and 3100 is present, and, if not, what then causes the two shallower basement reflections. The two deeper basement reflections can be traced down to about $6 \mathrm{~km}$ northwest of the proposed site and appear to offset other reflections on the seismic section (Fig. 7). These two must surely be located in the Precambrian basement. One possible disadvantage with the location is that the separation between these four deeper reflections is small, at least on the present processing, and it may be difficult in the borehole to strictly identify the source to each of the four reflections. However, a combination of new high-resolution seismic data and borehole seismic data should allow the source of the reflections to be determined without ambiguity.

Option 2 (Fig. 10b) is at a location (CDP 4100) where the sole thrust appears to be converging upwards towards the Jämtlandian décollement. The drill hole would penetrate the latter, as defined by a zone of flat-lying reflectivity between CDPs 3100 and 5200, at about $500 \mathrm{~m}$ depth; as in the Myrviken drill holes, it would be overlain by the shallow- 
est alum shales, the top of which occur at $400 \mathrm{~m}$, based on the MT data. The Jämtlandian décollement is underlain by a duplex structure, about $1 \mathrm{~km}$ thick, characterized by more steeply dipping, shorter reflections representing boundaries between Cambrian strata (quartzites and perhaps subordinate alum shales) and fragments of allochthonous Precambrian basement. The basal thrust of the duplex is a welldefined strong subhorizontal to gently NW-dipping reflection, present across the whole of Fig. 10b, between 1.3 and $1.9 \mathrm{~km}$ depth; this probably corresponds to the Caledonian sole thrust. At 2.2 to $2.3 \mathrm{~km}$ depth, a basement reflector that appears to extend westwards to depths of greater than $7 \mathrm{~km}$ would be penetrated by this hole. The reflection from this structure is rather weak at the proposed site, but clearly present.

\section{Conclusions}

An integrated interpretation of the geophysical and drill hole data (CSP, CCT, MT data, aeromagnetics) provides new constraints on the structure in the central part of the Scandinavian Caledonides. The Jämtlandian décollement, as identified in the Myrviken drill holes of the Caledonian thrust front, can be confidently traced westwards along the easternmost $20 \mathrm{~km}$ of the CSP, deepening in this section of the profile from about $0.5 \mathrm{~km}$ to nearly $1 \mathrm{~km}$. Further west, in our preferred interpretation, the Jämtlandian décollement continues to be relatively shallow, just somewhat greater than $1 \mathrm{~km}$ deep, even shallowing on a structural high, before rapidly deepening just east of the Seve Nappe Complex, in the eastern limb of the Åre Synform. The previously acquired CCT profile, together with new MT and magnetic data, is consistent with this interpretation of the Jämtlandian décollement; nevertheless, even somewhat deeper levels are possible.

The extent of Caledonian deformation below the Jämtlandian décollement and influencing the underlying basement, is less easily defined and the location of the Caledonian sole thrust remains enigmatic. It may indeed coincide with the surface defined by Hedin et al. (2012) at ca. $4.5 \mathrm{~km}$ depth beneath Åre, and then shallow eastwards, ramping up to converge with the Jämtlandian décollement near the end of the CSP and in the Myrviken area. However, deeper levels for the sole thrust beneath the CSP and farther to the west cannot be ruled out. The new data show mainly northwest-dipping structures below the uppermost $1-2 \mathrm{~km}$. Many of these structures have a similar pattern as those on the CCT profile located about $20 \mathrm{~km}$ to the north, suggesting large lateral continuity of the features out of the plane of the CSP. This is verified by the highly crooked Sällsjö profile in which reflections can be traced more than $5 \mathrm{~km}$ to the south of the CSP. A definite interpretation of these NW-dipping reflections is not possible without drilling into them. The reflectivity pattern suggests that they are Caledonian, or possibly reactivated older structures.
Two potential locations for the COSC-2 borehole have been identified along the CSP. Drilling at the more westerly site, on the south side of Lake Liten, will penetrate the full Silurian to Ediacaran stratigraphy and allow detailed analysis of the structure of the Jämtlandian décollement, defined by strong flat-lying reflections. It will also penetrate four strong reflections below the interpreted Jämtlandian décollement, allowing identification of the composition, structural characteristics, and timing of deformation of these features. Drilling at the alternative site, about $20 \mathrm{~km}$ farther southeast, will provide important evidence about the Jämtlandian décollement and possibly also the sole thrust. However, it may fail to provide unambiguous evidence about the character of the typical NW-dipping reflections in the basement, their reflectivity being somewhat diffuse at this potential site. Therefore, we favor the western site for the COSC-2 borehole.

Acknowledgements. The COSC project is a part of the Swedish Scientific Drilling Program (SSDP) which operates within the framework of the International Continental Scientific Drilling Program (ICDP), and the seismic reflection component of the project was funded by the Swedish Research Council (VR, grant 2013-5780). P. Hedin is also partly funded by VR. Hans Palm (HasSeis) planned and oversaw the seismic acquisition. GLOBE Claritas ${ }^{\mathrm{TM}}$ under license from the institute of Geological and Nuclear Sciences Limited, Lower Hutt, New Zealand, was used to process the seismic data, and seismic figures were prepared with the Generic Mapping Tools from P. Wessel and W. H. F. Smith. The applied geophysics group at Uppsala University is thanked for valuable discussions and advice throughout this work. We thank reviewers Puy Ayarza and Don White for constructive feedback on this manuscript.

Edited by: J. Alvarez-Marron

\section{References}

Andersson, A., Dahlman, B., Gee, D. G., and Snäll, S.: The Scandinavian alum shales, Geological Survey of Sweden, Ca 56, 1985.

Andreasson, P.-G.: The Baltoscandian margin in NeoproterozoicEarly Paleozoic time, Some constraints on terrain derivation and accretion in the arctic Scandinavian Caledonides, Tectonophysics, 231, 1-32, doi:10.1016/0040-1951(94)90118-X, 1994.

Braathen, A., Nordgulen, Ø., Osmundsen, P.-T., Andersen, T. B., Solli, A., and Roberts, D. Devonian, orogenparallel, opposed extension in the Central Norwegian Caledonides, Geology, 28, 615-618, doi:10.1130/00917613(2000)28<615:DOOEIT>2.0.CO;2, 2000.

Corfu, F., Gasser, D., and Chew, D. M.: New Perspectives on the Caledonides of Scandinavia and Related Areas, Geol. Soc. Spec. Publ., 390, ISBN: 978-1-86239-377-6, 2014.

Cosma, C. and Enescu, N.: Characterization of fractured rock in the vicinity of tunnels by the swept impact seismic technique, Int. J. Rock Mech. Min., 38, 815-821, doi:10.1016/S13651609(01)00046-6, 2001. 
Dewey, J. Evolution of the Appalachian/Caledonian Orogen, Nature, 222, 124-129, doi:10.1038/222124a0, 1969.

Dyrelius, D.: Aeromagnetic interpretation in a geotraverse area across the central Scandinavian Caledonides, GFF, 102, 421438, doi:10.1080/11035898009454498, 1980.

Dyrelius, D.: A Geophysical Perspective of the Scandinavian Caledonides, in: The Caledonide Orogen - Scandinavia and related areas, edited by: Gee, D. G. and Sturt, B. A., John Wiley \& Sons Ltd., Chichester, UK, ISBN: 0-471-10504-X, 185-194, 1985.

Dyrelius, D.: Gravity and magnetics in the central Scandes, GFF, 108, 278-280, doi:10.1080/11035898609454705, 1986.

Dyrelius, D., Gee, D. G., Gorbatschev, R., Ramberg, H., and Zachrisson, E.: A profile through the central Scandinavian Caledonides, Tectonophysics, 69, 247-284, doi:10.1016/00401951(80)90213-9, 1980.

Elming, S.-Å.: Geological modelling based on gravity data from the central part of the Swedish Caledonides, GFF, 110, 317-327, doi:10.1080/11035898809452666, 1988.

England, R. W. and Ebbing, J.: Crustal structure of central Norway and Sweden from integrated modelling of teleseismic receiver functions and the gravity anomaly, Geophys. J. Int., 191, 1-11, doi:10.1111/j.1365-246X.2012.05607.x, 2012.

Fossen, H., Gabrielsen, R. H., Faleide, J. I., and Hurich, C. A.: Crustal stretching in the Scandinavian Caledonides as revealed by deep seismic data, Geology, 42, 791-794, doi:10.1130/G35842.1, 2014.

Gee, D. G.: A tectonic model for the central part of the Scandinavian Caledonides, Am. J. Sci., A275, 468-515, 1975.

Gee, D. G.: Nappe displacement in the Scandinavian Caledonides, Tectonophysics, 47, 393-419, doi:10.1016/00401951(78)90040-9, 1978.

Gee, D. G.: Basement-cover relationships in the central Scandinavian Caledonides, GFF, 102, 455-474, doi:10.1080/11035898009454500, 1980.

Gee, D. G.: Thrust Tectonics in the Scandes - upper crustal extension during Scandian compression, GFF, 110, 390-392, doi:10.1080/11035898809452682, 1988.

Gee, D. G. and Sturt, B. A.: The Caledonide Orogen - Scandinavia and related areas, John Wiley \& Sons Ltd., Chichester, UK, ISBN: 0-471-10504-X, 1985.

Gee, D. G., Kumpulainen, R., and Thelander, T.: The Tåsjön Décollement, Central Swedish Caledonides, Geological Survey of Sweden, C 742, 1978.

Gee, D. G., Snäll, S., and Stejskal, V.: Alunskiffer projektet Fjällen. Undersökningar mellan Östersund och Svenstavik. Rapport till NSG. BRAP 82502, Geological Survey of Sweden, unpublished report, 36 pp., 1982.

Gee, D. G., Kumpulainen, R., Roberts, D., Stephens, M. B., Zachrisson, E., and Thon, A. Scandinavian Caledonides Tectonostratigraphic Map, Scale 1:2000 000, Geological Survey of Sweden, Ba 35, 1985.

Gee, D. G., Juhlin, C., Pascal, C., and Robinson, P.: Collisional Orogeny in the Scandinavian Caledonides (COSC), GFF, 132, 29-44, doi:10.1080/11035891003759188, 2010.

Gee, D. G., Janak, M., Majka, J., Robinson, P., and van Roermund, H.: Subduction along and within the Baltoscandian margin during closing of the Iapetus Ocean and Baltica-Laurentia collision, Lithosphere, 5, 169-178, doi:10.1130/L220.1, 2012.
Grip, E.: The Lead deposits of the eastern borders of the Caledonides in Sweden, 21st International Geological Congress, Copenhagen, Denmark, Reports 16, 149-159, 1960.

Hedin, P., Juhlin, C. and Gee, D. G.: Seismic imaging of the Scandinavian Caledonides to define ICDP drilling sites, Tectonophysics, 554-557, 30-41, doi:10.1016/j.tecto.2012.05.026, 2012.

Hedin, P., Almqvist, B. S. G., Berthet, T., Juhlin, C., Buske, S., Simon, H., Giese, R., Krauß, F., Rosberg, J.-E., and Alm, P.G.: 3-D reflection seismic imaging at the $2.5 \mathrm{~km}$ deep COSC-1 scientific borehole, central Scandinavian Caledonides, Tectonophysics, doi:10.1016/j.tecto.2015.12.013, in press, 2016.

Higgins, A. K. and Leslie, A. G.: Restoring thrusting in the East Greenland Caledonides, Geology, 28, 1019-1022, doi:10.1130/0091-7613(2000)28<1019:RTITEG>2.0.CO;2, 2000.

Högdahl, K., Andersson, U. B., and Eklund, O.: The Trans Scandinavian Igneous Belt (TIB) in Sweden: A review of its character and evolution, Geological Survey of Finland, Special Paper 37, Espoo, Finland, ISBN: 951-690-889-6, 2004.

Hossack, J. R. and Cooper, M. A.: Collision tectonics in the Scandinavian Caledonides, in: Collision Tectonics, edited by: Coward, M. P. and Ries, A. C., Geol. Soc. Spec. Publ. 19, 285-304, doi:10.1144/GSL.SP.1986.019.01.16, 1986.

Hurich, C. A.: Kinematic evolution of the lower plate during intracontinental subduction: An example from the Scandinavian Caledonides, Tectonics, 15, 1248001263, doi:10.1029/96TC00828, 1996.

Hurich, C. A., Palm, H., Dyrelius, D., and Kristoffersen, Y.: Deformation of the Baltic continental crust during Caledonide intracontinental subduction: views from seismic reflection data, Geology, 17, 423-425, doi:10.1130/00917613(1989)017<0423:DOTBCC>2.3.CO;2, 1989.

Juhlin, C.: Interpretation of the reflections in the Siljan Ring area based on results from the Gravberg-1 borehole, Tectonophysics, 173, 345-360, doi:10.1016/0040-1951(90)90229-2, 1990.

Juhojuntti, N., Juhlin, C., and Dyrelius, D.: Crustal reflectivity underneath the Central Scandinavian Caledonides, Tectonophysics, 334, 191-210, doi:10.1016/S0040-1951(00)00292-4, 2001.

Karis, L. and Strömberg, A. G. B.: Beskrivning till berggrundskartan över Jämtlands län. Del 2: Fjälldelen. Geological Survey of Sweden, Ca 53, Uppsala, Sweden, 1998.

Korja, T., Smirnov, M., Pedersen, L. B., and Gharibi, M. Structure of the central Scandinavian Caledonides and the underlying Precambrian basement, new constraints from magnetotellurics, Geophys. J. Int., 175, 55-69, doi:10.1111/j.1365246X.2008.03913.x, 2008.

Krauß, F., Simon, H., Giese, R., Buske, S., Hedin, P., and Juhlin, C. Zero-Offset VSP in the COSC-1 borehole, Geophysical Research Abstracts, 17, EGU2015-3255, 2015.

Labrousse, L., Hetényi, G., Raimbourg, H., Jolivet, L., and Andersen, T. B.: Initiation of crustal-scale thrusts triggered by metamorphic reactions at depth: Insights from a comparison between the Himalayas and Scandinavian Caledonides, Tectonics, 29, 114, doi:10.1029/2009TC002602, 2010.

Ladenberger, A., Gee, D. G., Be'eri-Shlevin, Y., Claesson, S., and Majka, J.: The Scandian collision revisited - when did the orogeny start? Geophysical Research Abstracts, 14, EGU201512633, 2012. 
Ladenberger, A., Be'eri-Shlevin, Y., Claesson, S., Gee, D. G., Majka, J., and Romanova, I. V.: Tectonometamorphic evolution of the Areskutan Nappe - Caledonian history revealed by SIMS U-Pb zircon geochronology. in: New Perspectives on the Caledonides and Related Areas, edited by: Corfu, F., Gasser, D., and Chew, D. M., Geol. Soc. Spec. Publ., 390, 337-368, doi:10.1144/SP390.10, 2014.

Li, Y., Gee, D. G., Almqvist, B. S. G., Klonowska, I., Lorenz, H., Ladenberger, A., Majka, J., and Sjöström, H.: Mid Ordovician Leucogranites in the Lower Seve Nappe of central Jämtland, Swedish Caledonides, in: Abstract Volume Geological Society of Sweden, Lund, p. 118, 2014.

Lindström, M., Sturkell, E., Törnberg, R., and Ormouml, J.: The marine impact crater at Lockne, central Sweden, GFF, 118, 193 206, doi:10.1080/11035899609546255, 1996.

Lorenz, H., Gee, D., and Juhlin, C.: The Scandinavian Caledonides - Scientific Drilling at Mid-Crustal Level in a Palaeozoic Major Collisional Orogen, Sci. Dril., 11, 60-63, doi:10.2204/iodp.sd.11.10.2011, 2011.

Lorenz, H., Rosberg, J.-E., Juhlin, C., Bjelm, L., Almqvist, B. S. G., Berthet, T., Conze, R., Gee, D. G., Klonowska, I., Pascal, C., Pedersen, K., Roberts, N. M. W., and Tsang, C.-F.: COSC1 - drilling of a subduction-related allochthon in the Palaeozoic Caledonide orogen of Scandinavia, Sci. Dril., 19, 1-11, doi:10.5194/sd-19-1-2015, 2015.

Majka, J., Be'eri-Shlevin, Y., Gee, D. G., Ladenberger, A., Claesson, S., Konečny, P., and Klonowska, I.: Multiple monazite growth in the Åreskutan migmatite: Evidence for a polymetamorphic Late Ordovician to Late Silurian evolution in the Seve Nappe Complex of west-central Jämtland, Sweden. J. Geosci. 57, 3-23, doi:10.3190/jgeosci.112, 2012.

Mosar, J.: Scandinavia's North Atlantic passive margin, J. Geophys. Res., 108, 2360, doi:10.1029/2002JB002134, 2003.

Palm, H.: Time-delay interpretation of seismic refraction data in the Caledonian front, Jämtland, central Scandinavian Caledonides, GFF, 106, 1-14, doi:10.1080/11035898409454597, 1984.

Palm, H., Gee, D. G., Dyrelius, D., and Björklund, L.: A reflection seismic image of Caledonian structure in Central Sweden, Geological Survey of Sweden, Ca 75, 1991.

Park, C. B.: Swept impact seismic technique (SIST), Geophysics, 61, 1789-1803, doi:10.1190/1.1444095, 1996.

Pascal, C., Ebbing, J., and Skilbrei, J. R.: Interplay between the Scandes and the Trans-Scandinavian Igneous Belt: Integrated thermo-rheological and potential field modelling of the Central Scandes profile, Nor. Geol. Tidsskr., 87, 3-12, 2007.

Place, J., Malehmir, A., Högdahl, K., Juhlin, C., and Nilsson, K.: Seismic characterization of the Grängesberg iron deposit and its mining-induced structures, central Sweden, Interpretation, 3, SY41-SY56, doi:10.1190/INT-2014-0212.1, 2015.

Reynolds, J. M.: An Introduction to Applied and Environmental Geophysics, 2nd ed., Wiley-Blackwell, Chichester, UK, ISBN: 978-0-471-48535-3, 2011.
Robinson, P., Roberts, D., Gee, D. G., and Solli, A.: A major synmetamorphic Early Devonian thrust and extensional fault system in the Mid Norway Caledonides: relevance to exhumation of HP and UHP rocks. in: New Perspectives on the Caledonides and Related Areas, edited by: Corfu, F., Gasser, D., and Chew, D. M., Geol. Soc. Spec. Publ., 390, 241-270, doi:10.1144/SP390.24, 2014.

Saintilan, N. J., Stephens, M. B., Lundstam, E., and Fontboté, L.: Control of reactivated basement structures on sandstonehosted $\mathrm{Pb}-\mathrm{Zn}$ deposits along the Caledonian front, Sweden: Evidence from airborne magnetic field data, structural analysis and ore grade modeling, Econ. Geol., 110, 91-117, doi:10.2113/econgeo.110.1.91, 2015.

Sjöström, H. and Talbot, C.: Caledonian and Post-Caledonian structure of the Olden Window, Scandinavian Caledonides, GFF, 109, 359-361, doi:10.1080/11035898709453109, 1987,

Sjöström, H., Bergman, S. and Sokoutis, D. Nappe geometry, basement structure and normal faulting in the central Scandinavian Caledonides; kinematic implications, GFF, 113, 265-269, doi:10.1080/11035899109453877, 1991.

Söderlund, U., Elming, S.-Å., Ernst, R. E., and Schissel, D.: The Central Scandinavian Dolerite Group-Protracted hotspot activity or back-arc magmatism? Constraints from U-Pb baddeleyite geochronology and Hf isotopic data, Precambrian Res., 150, 136-152, doi:10.1016/j.precamres.2006.07.004, 2006.

Sopher, D., Juhlin, C., Huang, F., Ivandic, M., and Lueth, S.: Quantitative assessment of seismic source performance: Feasibility of small and affordable seismic sources for long term monitoring at the Ketzin $\mathrm{CO}_{2}$ storage site, Germany, J. Appl. Geophys., 107, 171-186, doi:10.1016/j.jappgeo.2014.05.016, 2014.

Stolt, R. H.: Migration by Fourier transform, Geophysics, 43, 23 48, doi:10.1190/1.1440826, 1978.

Strand, T. and Kulling, O.: Scandinavian Caledonides, Wiley Interscience, London, UK and New York, USA, 302 pp., 1972.

Strömberg, A., Karis, L., Zachrisson, E., Sjöstrand, T., Skoglund, R., Lundegårdh, P. H., Gorbatschev, R., and Kornfält, K.-A.: Berggrundskarta över Jämtlands län utom förutvarande Fjällsjö kommun, scale 1: 200000 , Geological Survey of Sweden, Ca 53, Geological Map, Uppsala, Sweden, 1984.

Tiren, S. A.: Thrust Nappe Geometry in the northern part of the Mullfjället Antiform, Jämtland Caledonides, Sweden, Terra Cognita, 1, p. 79, 1981.

Törnebohm, A. E.: Om fjällproblemet, GFF, 10, 328-336, doi:10.1080/11035898809444211, 1888.

Yan, P., Juanatey, M. A. G., Kalscheuer, T., Juhlin, C., Hedin, P., Savvaidis, A., and Lorenz, H.: A magnetotelluric investigation in the Scandinavian Caledonides in western Jämtland, central Sweden, using the COSC-1 borehole log as a priori information, Geophys. J. Int., in review, 2016. 